\title{
The Ubiquitin-Proteasome System and DNA Repair
}

\author{
Christine A. Falaschetti, Emily C. Mirkin, Sumita Raha, \\ Tatjana Paunesku and Gayle E. Woloschak \\ Department of Radiation Oncology, Feinberg School of Medicine \\ and Robert H. Lurie Cancer Center, Northwestern University
}

USA

\section{Introduction}

The 2004 Nobel Prize in Chemistry was awarded to Aaron Ciechanover, Avram Hershko, and Irwin Rose for their work in discovering the ubiquitin-proteasome system (UPS), as reviewed by Herrmann and others (Herrmann et al., 2007). The mechanisms by which proteolysis occurs had remained elusive until the late 1970s, when a series of key experiments paved the way for a new area of research (Ciechanover et al., 1978; Ciechanover et al., 1980b; Hershko et al., 1980). These studies revealed that the majority of protein degradation is nonlysosomal and adenosine triphosphate (ATP)-dependent. Most importantly, it was also demonstrated that this proteolysis requires at least two components: one with protease activity and another in the form of an 8.5-kDa heat-stable protein. These elements were later identified as the proteasome and ubiquitin, respectively (Ciechanover et al., 1980a; Wilkinson et al., 1980; Hough et al., 1986; Waxman et al., 1987; Arrigo et al., 1988). Substrates of the UPS include many short-lived regulatory proteins in addition to misfolded and defective proteins (Dahlmann, 2007; Naiki \& Nagai, 2009; Xie, 2010). Conserved from Archaea to humans, the UPS is thought to be responsible for degrading approximately $90 \%$ of nuclear and cytoplasmic proteins (Magill et al., 2003). Through regulation of protein expression, the UPS controls processes such as protein homeostasis, cell-cycle, cell division, cellular differentiation, apoptosis, signal transduction, gene expression, immunity, and DNA repair (Magill et al., 2003; Finley, 2009; Liggett et al., 2010; Shabek \& Ciechanover, 2010; Xie, 2010). Although much focus on this system revolves around its proteolytic function and regulation, members of the UPS also play non-proteolytic roles in transcription, membrane trafficking, protein kinase activation, chromatin dynamics, and DNA repair (Chen \& Sun, 2009; Xie, 2010).

The UPS plays one of the central roles in pathology and disease, and it has become the target of several newer therapeutic modalities. In patients with some forms of cardiac dysfunction, neurodegeneration, autoimmune disease, and viral infections, proteasome activity and/or expression is diminished (Magill et al., 2003; Dahlmann, 2007; Naiki \& Nagai, 2009). Conversely, in some cancer patients and patients with cachexia, an increase in proteasome expression has been observed. According to the idea that this increase in proteosome activity is a potential therapeutic target, proteosome inhibitors are developed and isolated from natural products (Orlowski \& Kuhn, 2008; Groll et al., 2009; Huang \& Chen, 2009). 
Most notably, bortezomib (Velcade, PS-341) is the first FDA approved proteasome inhibitor and has been used with some success in the treatment of multiple myeloma and mantle cell lymphoma patients (Palombella et al., 1998; Hideshima et al., 2001; Russo et al., 2007).

This chapter is focused on the UPS and its interaction with DNA repair. DNA can be damaged by a wide variety of environmental stresses (ionizing radiation, Ultraviolet (UV) radiation, chemicals) and endogenous cellular metabolites; these DNA damages include base-damage lesions, single-strand breaks (SSBs), double-strand breaks (DSBs), DNA-DNA and DNA-protein crosslinks, as well as other adducts (Sharova, 2005a; Huang \& D'andrea, 2006). Consequently, cells have evolved a number of DNA repair pathways in order to remove or mend these lesions quickly and efficiently to preserve genomic integrity. The connection between DNA repair and the UPS was first revealed when Jentsch and colleagues showed that the DNA repair gene Rad6 encodes a ubiquitin-conjugating enzyme (Jentsch et al., 1987). Following this finding, the study of UPS-regulated DNA repair has expanded immensely. Specifically, this chapter will revolve around the UPS as it relates to the nucleotide excision repair (NER), base excision repair (BER), mismatch repair (MMR), double-strand break (DSB) repair, post-replication repair (PRR), and Fanconi anemia (FA) pathways. We will explore the extent to which representative DNA repair proteins of these pathways directly interact with members of the UPS and depend upon the proteolytic and non-proteolytic roles of the UPS. Finally, despite the fact that the mechanisms of action of proteasome inhibitors are not wholly understood (Drexler, 1997), current evidence suggests that DNA repair pathways are key targets of bortezomib treatment.

\section{The ubiquitin-proteasome system}

The UPS contains both substrate-recruiting and substrate-degrading machinery (Dahlmann, 2007). The central element of this intricate system, the proteasome, is a highly abundant and stable cellular protein complex (Liggett et al., 2010). A number of proteasome-associated proteins have been identified, which may either enhance or suppress UPS-mediated proteolysis, and yeast genetics has contributed greatly to the understanding of the UPS by facilitating its manipulation (Finley, 2009).

\subsection{Structure of the proteasome}

The 2.5-MDa proteasome can exist in several forms organized into two main subcomplexes: the 28-subunit core particle (CP or $20 \mathrm{~S}$ proteasome) and the 19-subunit regulatory particle (RP, 19S proteasome, or PA700) (Finley, 2009; Xie, 2010). The 20S proteasome is a barrel-like structure composed of four stacked heptameric rings. The outer rings consist of one of seven unique alpha-subunits and the inner rings are composed of one of seven unique betasubunits, a configuration that may be represented as: $\alpha_{1-7} \beta_{1-7} \beta_{1-7} a_{1-7}$ (Groll et al., 1997; Navon $\&$ Ciechanover, 2009). The largest dimensions of the interior of the $20 \mathrm{~S}$ proteasome are approximately $100 \AA$ axially and $60 \AA$ orthogonally (Finley, 2009). However, crystal structures of the $20 \mathrm{~S}$ proteasome show that the entry ports of the alpha-subunits are as narrow as 10-13 $\AA$ (Groll et al., 1997), which helps to prevent spontaneous protein degradation.

The $20 S$ proteasome supports three main catalytic activities: (1) the $\beta 1$-subunit has caspaselike activity and cleaves peptide bonds after acidic residues; (2) the $\beta 2$-subunit possesses trypsin-like activity and cleaves after basic residues; and (3) the $\beta 5$-subunit carries chymotrypsin-like activity and cleaves after large, hydrophobic residues (Orlowski \& Wilk, 
2000). The catalytic subunits of the $20 \mathrm{~S}$ proteasome degrade proteins into a heterogeneous mixture of peptides rather than into single amino acids (Kisselev et al., 1999; Goldberg et al., 2002). Proteasomal inhibitors interfere with these activities to various degrees and with specificities for one or more of the main catalytic activities (Groll et al., 2009).

The 19S proteasome is attached to one or both ends of the $20 \mathrm{~S}$ proteasome, and the resulting complex is known as the $26 \mathrm{~S}$ proteasome. Although no crystal structure for the $19 \mathrm{~S}$ proteasome has yet been solved, it is currently believed that the 19S proteasome can be separated into two additional subcomplexes: the base and the lid. The base is composed of six AAA ATPase (ATPases Associated with diverse cellular Activities) subunits (Rpt1-6 in Saccharomyces cerevisiae) as well as three non-ATPase subunits (Rpn1, Rpn2, and Rpn13 in $S$. cerevisiae). The lid includes at least nine non-ATPase subunits (Rpn3, Rpn5-9, Rpn11, Rpn12, and Rpn15 in S. cerevisiae). Additionally, the yeast protein Rpn10 appears to stabilize the connection between the base and the lid (Finley, 2009; Xie, 2010).

\subsection{Function of the UPS}

Protein substrates targeted for proteasomal degradation must first be tagged by ubiquitin, a highly conserved 76 amino acid protein. This process is carried out by the concerted activities of three categories of enzymes: a ubiquitin-activating enzyme (E1), a ubiquitinconjugating enzyme (E2), and a ubiquitin-protein ligase (E3) (Dahlmann, 2007; Chen \& Sun, 2009; Navon \& Ciechanover, 2009; Shabek \& Ciechanover, 2010). According to recent counts, humans have genes for two E1, roughly 40 E2, and approximately 600 E3 enzymes (Chen \& Sun, 2009; Hofmann, 2009). In the first step of the reaction, E1 activates the ubiquitin polypeptide in an ATP-dependent process, and the activated ubiquitin molecule is subsequently transferred onto E2 by a thioester bond. E3 can then bind the activated ubiquitin to a substrate protein; the high degree of specificity of this enzyme dictates the specificity by the UPS (Magill et al., 2003). An isopeptide bond is formed between the Cterminal glycine (G76) of ubiquitin and the $\varepsilon$-amino group of a lysine on the targeted protein. Next, a polyubiquitin chain is generated through repetition of this process on the ubiquitin molecules themselves. Although ubiquitin contains seven lysine residues (K6, K11, $\mathrm{K} 27, \mathrm{~K} 29, \mathrm{~K} 33, \mathrm{~K} 48$, and K63), new ubiquitin moieties are conjugated most often to K48 of the previously attached ubiquitin molecule (Varshavsky, 1997; Hershko et al., 2000; Schwartz \& Ciechanover, 2009). A chain of at least four ubiquitin proteins linked through K48 is recognized by the $26 \mathrm{~S}$ proteasome for degradation (Figure 1). It appears as though K48 has a rather exclusive role in the formation of ubiquitin-mediated degradation signals; the other six lysines of ubiquitin can play either proteolytic or non-proteolytic roles when engaged to form polyubiquitin chains (Chen \& Sun, 2009).

Ubiquitin-like proteins (UBLs) are structurally similar to ubiquitin and utilize a comparable enzyme cascade consisting of UBL-activating (E1), UBL-conjugating (E2), and UBL-ligase (E3) enzymes (Huang \& D'andrea, 2006). Among UBLs, SUMO (small ubiquitin-like modifier) and NEDD8 (neuronal-precursor-cell-expressed developmentally downregulated protein-8) are the best characterized. SUMO exists in at least four mammalian isoforms (SUMO-1,2,3,4). The process of sumoylation, which is ATP-dependent and generally has nondegradative functions, is reversibly executed by SUMO isopeptidases (Johnson, 2004). NEDD8 (Rub1 in S. cerevisiae) also does not directly signal proteolysis but rather regulates E3 ubiquitin-protein ligases and covalently binds to the Cullin family of E3 complexes (Hori et al., 1999). 
Entry of substrates into the multicatalyic $20 \mathrm{~S}$ proteasome is regulated and stimulated by the 195 proteasome. Rpn11 and Rpn13 of the 19S proteasome, and three proteasome-associated proteins, Rad23, Dsk2, and Ddi1, serve as ubiquitin receptors (Finley, 2009). These latter proteins weakly bind to the proteasome and are termed UBL/UBA shuttle proteins due to their ubiquitin-like (UBL) and ubiquitin-associated (UBA) domains (Finley, 2009). Prior to degradation, the ubiquitin moieties must be removed and the protein substrates unfolded. Rpn11 in yeast (Poh1 in humans) serves as a deubiquitinating enzyme (DUB) in the presence of ATP and cooperates with two other deubiquitinases, Upb6 and Uch37 (Usp14 in mammals) (Finley, 2009). Mammals possess about 90 known DUBs for cleaving polyubiquitin chains or for removing ubiquitin from protein substrates (Chen \& Sun, 2009; Hofmann, 2009). Although substrate unfolding and translocation are not completely understood, it is currently believed that the six ATPases of the 195 base unfold target proteins and open the gate of the $20 \mathrm{~S}$ so that substrate proteins may reach the proteolytic sites (Finley, 2009; Shabek \& Ciechanover, 2010).

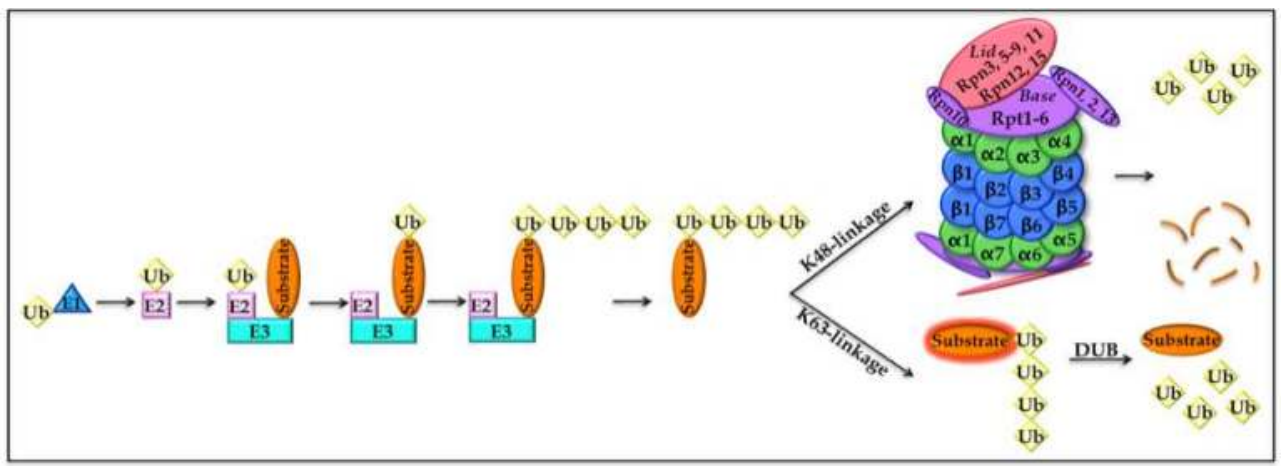

Fig. 1. Schematic representation of UPS-mediated protein regulation. A protein substrate (orange) is tagged with a polyubiquitin chain upon the activities of E1, E2, and E3 enzymes. Substrates modified by a K48-linked polyubiquitin chain are processed and degraded by the $26 \mathrm{~S}$ proteasome, consisting of a $20 \mathrm{~S}$ core and $19 \mathrm{~S}$ regulatory particles. Oppositely, K63linkages are attributed to non-proteolytic functions and can allow for functional alterations of the tagged substrate.

\subsection{The UPS and general repair proteins}

Two proteins closely linked with DNA repair in general and regulated by the UPS are p53 and PCNA. In both cases, their UPS regulation can be either proteolytic or non-proteolytic (Coutts et al., 2009; Ulrich, 2009). p53 is regulated by the UPS in a way that prevents unnecessary cell death or cell-cycle arrest (Stehmeier \& Muller, 2009). p53 interacts with the 195 proteasome in vitro and in vivo (Zhu et al., 2007) and can be both mono- or polyubiquitinated (Stehmeier \& Muller, 2009). Mdm2, a ubiquitin-protein ligase, promotes the ubiquitination and consequent degradation of p53 as well as the conjugation of NEDD8 (Zhang \& Xiong, 2001; Xirodimas et al., 2004). NEDD8 conjugation appears to weaken the inhibition of p53, and this ubiquitination and NEDDylation of p53 are independently regulated upon DNA damage (Xirodimas et al., 2004). Additionally, both p53 and Mdm2 are modified by SUMO-1 (Chen \& Chen, 2003). Only a small fraction of p53 is sumoylated, and 
the possible role of p53 sumoylation in degradation and DNA repair is still being investigated (Stehmeier \& Muller, 2009).

Similarly, proliferating cell nuclear antigen (PCNA), a processivity clamp for the replicative and repair DNA polymerases, is a target of the UPS (Paunesku et al., 2001; Ulrich, 2009). In yeast, PCNA is modified by SUMO at the beginning of S-phase (Papouli et al., 2005; Pfander et al., 2005); however, in response to DNA damage, PCNA is monoubiquitinated in a Rad6/Rad18 dependent manner (Hoege et al., 2002; Lee \& Myung, 2008). Further modification with a K63-linked polyubiquitin chain can then occur pending the interaction of Rad5, a ubiquitin-protein ligase, and Ubc13-Mms2, a ubiquitin-conjugating dimer (Hofmann, 2009). Monoubiquitinated and polyubiquitinated PCNA proteins are involved in different DNA repair mechanisms. Proteins PTIP/Swift, an adapter for checkpoint kinases ATM and ATR, and ubiquitin specific protease 1 (USP1) deubiquitinate PCNA (Huang et al., 2006; Ulrich, 2009). Finally, tight regulation of PCNA ubiquitination, keeping ubiquitinated PCNA at low levels in undamaged cells, prevents the recruitment of translesion synthesis (TLS) polymerases, an event that could lead to mutagenesis (Lee \& Myung, 2008). For more on PCNA, see section 7.

\section{Nucleotide excision repair}

Nucleotide excision repair (NER) is an evolutionarily conserved, multistep mechanism responsible for removing bulky chemical adducts and UV-induced photoproducts from DNA (Sharova, 2005a). NER can be divided into repair of overall genomic DNA [global genome repair (GGR)] and repair of actively transcribing genes [transcription-coupled repair (TCR)] (Mueller \& Smerdon, 1996). Approximately 30 proteins participate in NER. In this relatively error-free repair process, sites of DNA damage are first recognized and bound by a multi-protein complex. The damaged strand is then cleaved several nucleotides away from the $5^{\prime}$ and $3^{\prime}$ ends of the affected oligonucleotide. Upon removal of this fragment, the resulting $\sim 30$ nucleotide gap is filled by DNA polymerases $\delta$ and $\varepsilon$ in a PCNA-dependent manner, and a DNA ligase covalently attaches the $3^{\prime}$ end of the newly synthesized strand to the flanking DNA (Lommel et al., 2000). Defects in NER are associated with diseases such as Xeroderma Pigmentosum, Cockayne's Syndrome, and Trichothiodystrophy (Bergoglio \& Magnaldo, 2006; Leibeling et al., 2006).

\subsection{Nucleotide excision repair enzymes and the UPS}

In mammalian cells, the first step of NER initiation after damage involves the DamagedDNA binding protein (DDB) complex that recognizes sites of complex adducts, including those induced by UV radiation (Stoyanova et al., 2009; Iovine et al., 2011). Two protein members of this complex, DDB1 and DDB2, associate with the Cullin 4A (Cul4A) ubiquitin E3 complex, which has been shown to polyubiquitinate Xeroderma pigmentosum $\mathrm{C}$ protein (XPC) (Stoyanova et al., 2009; Iovine et al., 2011). DDB1 regulates cyclin-dependent kinase inhibitor 1B (p27) levels after low-dose UV irradiation (Iovine et al., 2011). DDB2 associates with COP9 Signalosome complex (CSN), which has structural homology to the 195 proteasome (Groisman et al., 2003). DDB2 also regulates levels of cyclin-dependent kinase inhibitor 1 (Cip1 or p21) and phospho-p53 through the UPS (Stoyanova et al., 2009). Interestingly, DDB2 is targeted by Cul4A and polyubiquitinated after UV irradiation (Bergink et al., 2007; Stoyanova et al., 2009; Iovine et al., 2011). Therefore, both DDB2 and $\mathrm{XPC}$ are downregulated by Cul4A, but protein degradation in this situation promotes a 
more efficient DNA repair, as explained further later. No homolog of DDB2 is found in yeast, but a comparable E3 enzyme complex containing Rad16, Rad7, Cul3, and Elc1 is linked to GGR in yeast (Gillette et al., 2006; Dantuma et al., 2009).

Following UV irradiation, ubiquitin and SUMO-1 modify XPC in a manner dependent on DDB2 and XPA (Wang et al., 2005b). XPC in mammalian cells and Rad7 and Rad16 in yeast are required for GGR (Chen et al., 2007). Cockayne syndrome complementation group A and B proteins (CSA and CSB) in mammals and Rpb9 and Rad26 (the homologue of CSB) in yeast are required for TCR (Chen et al., 2007). CSA and CSB are also necessary for ubiquitination of Rpb1, the largest subunit of RNA polymerase II (Pol II) (Chen et al., 2007). When DNA damage causes DNA Polymerase II to become stalled, Rpb1 is polyubiquitinated and degraded by the $26 \mathrm{~S}$ proteasome (Ribar et al., 2006; Chen et al., 2007). It does not appear as if the whole Pol II complex is degraded (Ribar et al., 2006), and Rpb9, another subunit of Pol II, mediates the ubiquitination of Rpb1 in response to UV radiation (Chen et al., 2007; Daulny \& Tansey, 2009). Conversely, the DUB Ubp3 deubiquitinates Pol II and prevents its degradation (Mao \& Smerdon, 2010).

Different types of histone modifications are associated with DNA repair, such as monoubiquitination of histone H2A following UV-damage (Bergink et al., 2006). Ubiquitinated $\mathrm{H} 2 \mathrm{~A}(\mathrm{uH} 2 \mathrm{~A})$ is the most common modification of histones in higher eukaryotes, and $\mathrm{uH} 2 \mathrm{~A}$ foci formation requires either functional GGR or TCR (Zhu et al., 2009). The E3 enzyme Cul4A-DDB has also been shown to ubiquitinate histones $\mathrm{H} 3$ and $\mathrm{H} 4$ in order to positively regulate NER (Zhu et al., 2009). Histone ubiquitination could play a role in chromatin remodelling and is dependent on RING2, an E3 enzyme, and ATR-kinase (Bergink et al., 2006). The pivotal yeast NER protein Rad4, the yeast homologue of XPC, is involved in this process. Rad4 binds to Snf5 and Snf6 of the Swi/Snf chromatin-remodelling complex (Gong et al., 2006), which correlates with UV-induced chromatin remodelling; this event could induce DNA to be more accessible to repair proteins (Dantuma et al., 2009). Interestingly, proteasome inhibitors such as lactacystin (LC) and N-acetyl-leucyl-leucylnorleucinal (ALLnL) deplete free cellular ubiquitin, thereby negatively affecting protein dynamics of histones, and promote chromatin condensation (Mimnaugh et al., 2000).

Yeast protein Rad23 is involved in both NER pathways: GGR and TCR (Mueller \& Smerdon, 1996). Rad23 itself is not degraded by the $26 \mathrm{~S}$ proteasome because it lacks an initiation region for the proteasome to engage and unfold it (Fishbain et al., 2011). However, Rad23 has been shown to contact proteins Rpt1 (Cim5), Rpt4 (Sug2), Rpt6 (Cim3/Sug1), Rpn1, and Rpn10 (S5a) of the 19S proteasome (Waters et al., 1993; Motegi et al., 2009), perhaps to recruit it to sites of DNA damage (Russell et al., 1999). The N-terminal domain of Rad23 (the UbL domain) resembles ubiquitin, which enables it to interact with the 26S proteasome directly (Watkins et al., 1993; Schauber et al., 1998). Notably, Rad23 has 22\% identical and $43 \%$ similar amino acid residues compared to ubiquitin from S. cerevisiae (Watkins et al., 1993; Schauber et al., 1998). Deletion of the UbL domain impairs Rad23 function, leading to UV-sensitivity and a 50\% decrease of NER activity in yeast (Watkins et al., 1993; Russell et al., 1999). This effect is reversed, however, upon substitution of the UbL domain with the sequence of ubiquitin (Watkins et al., 1993). E1-ubiquitin and E2-ubiquitin thioester intermediate formation does not appear to be affected by Rad23, but the presence of Rad23 remarkably stabilizes proteins in vivo and inhibits multi-ubiquitin chain assembly in vitro (Ortolan et al., 2000). The two UBA regions of Rad23 participate in noncovalent interactions with ubiquitin, and loss of both UBA regions does not allow Rad23 to block assembly of multi-ubiquitin chains on protein substrates (Chen et al., 2001). Interestingly, 
the C-termini of the human homologues to Rad23, hHR23A and hHR23B, contain a stretch of amino acids homologous to E2 enzymes (van der Spek et al., 1996; Masutani et al., 1997). The C-terminus of Rad23 binds with high affinity to Rad4 (Mimnaugh et al., 2000). Rad23/Rad4 complexes govern damage recognition and bind UV-irradiated DNA (Guzder et al., 1998; Jansen et al., 1998; Guzder et al., 1999); loss of Rad4 leads to severe UVsensitivity (Ortolan et al., 2000). Rad23 can regulate polyubiquitination of Rad4 in vivo and delay its degradation by the $26 \mathrm{~S}$ proteasome (Lommel et al., 2002). The Rad4 binding domain (R4B) of Rad23 is also sufficient to stabilize Rad4 and enable NER in yeast strains lacking Rad23 (Ortolan et al., 2004). Nevertheless, in a Rad23 null strain, overexpression of Rad4-hemagglutinin does not rescue the impaired repair of cyclobutane pyrimidine dimers (CPDs) (Lommel et al., 2002). Rad23 may protect Rad4 from degradation so that it can participate in NER, but Rad23 may also play proteolytic roles in other pathways (Ortolan et al., 2004). Essentially, optimal NER necessitates two distinct functions of Rad23; both $\operatorname{Rad} 23 /$ proteasome and $\operatorname{Rad} 23 / \operatorname{Rad} 4$ interactions are required for maximum UV-resistance (Ortolan et al., 2004).

Other yeast enzymes, Rad7 and Rad16, are also involved in UPS regulation of NER. These proteins are members of the nucleotide excision repair factor 4 (NEF4) complex, which bears E3 activity and regulates Rad4 levels (Ramsey et al., 2004). The DUB Upb3 promotes degradation of Rad4, which leads to a negative regulation NER; conversely, inactivation of Upb3 stabilizes Rad4 (Mao \& Smerdon, 2010).

Ubiquitination is necessary for NER, since E1 enzyme inactivation exerts a negative influence on NER in mammalian cells (Wang et al., 2005a). However, much debate surrounding NER and the UPS still exists, revolving around the question of whether UPSmediated modifications leading to proteolysis (a proteolytic role of the UPS) are more or less important for NER than the modifications (ubiquitination, sumoylation, etc.) that do not lead to protein degradation (a non-proteolytic role of the UPS). For example, Rad23 is not degraded by the proteasome, and this suggests that it has a non-proteolytic role (Watkins et al., 1993). Antibodies against the ATPases of the 195 have been shown to measurably lower NER activity, but mutations in $20 \mathrm{~S}$ subunits that severely curb proteolysis and incubation with proteosome inhibitor LC do not appear to change NER activity (Russell et al., 1999; Gillette et al., 2001). Also, efficient NER in yeast relies on two mechanisms related to the necessity of de novo protein synthesis, neither of which entails proteolytic behavior (Gillette et al., 2006). Rad23 and the 195 proteasome regulate one such pathway, independently of de novo protein synthesis. Another pathway involving Rad4 ubiquitination by a Rad7containing E3 ligase depends on de novo protein synthesis to restore Rad4 to baseline levels such as they were prior to DNA damage (Gillette et al., 2006). All these findings stress a connection between NER and non-proteolytic behavior of the UPS (Gillette et al., 2006).

However, NER has been shown to be increased in yeast strains with mutations in genes encoding the $26 \mathrm{~S}$ proteasome (Lommel et al., 2002). Proteosome inhibitors LC and ALLnL interfere with removal by NER of cisplatin-damaged DNA and decrease mRNA levels of the excision nuclease Ercc-1 in ovarian cancer cells (Mimnaugh et al., 2000). Treatment of normal human fibroblasts with proteosome inhibitors MG132 or LC decreases repair of CPDs (Wang et al., 2005a). Overexpression of hSug1, one of the six ATPases of the mammalian 19S proteasome, competes with endogenous 19S proteasomes for substrates and negatively affects NER (Wang et al., 2005a). In yeast, conditional proteasome mutants of Rpt1 and Rpt6 exhibit faster NER in a single gene repair study (Lommel et al., 2000). Similarly, overexpression of Rad4 results in increased NER of the transcribed and non- 
transcribed strands of the damaged gene. Therefore, proteosome subunit overexpression has an effect similar to overexpression of the NER protein Rad4, which results in increased GGR and TCR (Lommel et al., 2000).

Ultimately, this apparent discrepancy could stem from the use of different model systems because NER proteins and processes differ among different organisms (Wang et al., 2005a). The exact role(s) of the $26 \mathrm{~S}$ proteasome in NER remain somewhat obscured. There is no consensus on whether the 26S proteasome plays excitatory and/or inhibitory roles in NER, nor is the balance between the roles of Rad23 in DNA repair and proteolysis fully understood (Dantuma et al., 2009). It is unclear whether Rad23 is ubiquitinated itself, and if so, what is the significance of that modification (Dantuma et al., 2009). Nevertheless, evidence of "protein sharing" between the UPS and NER suggests a functional connection that is deeper than our present understanding of this system.

\section{Base excision repair}

The base excision repair (BER) pathway regulates removal of damaged bases, apurinic/apyrimidinic (AP) sites, and single-strand breaks (SSBs) induced by UV radiation, ionizing radiation, oxidative stressors, and alkylating agents (Dalhus et al., 2009; Wilson et al., 2010). For every double-stranded DNA break (DSB), cells sustain hundreds of SSBs; consequently, BER activity in cells is perpetually engaged. BER can be separated into longpatch repair and short-patch repair, dependent upon the type of lesion incurred as well as the expression levels of BER proteins (Memisoglu \& Samson, 2000; Wilson et al., 2010). The most fundamental steps of BER include damaged base recognition and removal by DNA glycosylases, strand cleavage by an AP endonuclease, incised strand processing, DNA synthesis, and ligation (Sharova, 2005a). Processing of gaps in mammalian DNA involves a DNA polymerase (primarily Pol $\beta$ ), DNA ligase IIIa, and X-ray crosscomplementing group1 protein (Xrcc1) (Parsons et al., 2010). Importantly, the BER, NER, and MMR activities can overlap in protection against DNA damage (Wilson et al., 2010), sharing proteins such as Rad4. Dysfunctional BER can lead to chromosomal rearrangements and cell death, and defects/knock-out animals for BER genes are often associated with embryonic lethality (Wilson \& Thompson, 1997).

\subsection{Base excision repair and the UPS}

While poly (ADP-ribose) polymerase-1 (PARP-1) does not appear to play an enzymatic role in BER, it is the molecule that recognizes DNA damage repaired by BER. Moreover, PARP inhibition delays repair of SSBs in Xrcc1-deficient cells (Strom et al., 2010) and protects SSBs from becoming DSBs, thereby ensuring that the SSBs may be repaired by BER proteins (Woodhouse et al., 2008). PARP-1 has been shown to be polyubiquitinated and modified by SUMO-1 and SUMO-3 in vitro and in vivo (Wang et al., 2008; Messner et al., 2009). Polyubiquitination of PARP-1 requires proteasomal inhibition, indicating that it is a target of the $26 \mathrm{~S}$ proteasome (Wang et al., 2008). In a yeast two-hybrid screen, PARP was found to interact with hUbc9, the human protein homologous to Ubc9, a yeast E2 enzyme (Masson et al., 1997). $h U b c 9$ mRNA has been shown to increase at the beginning of S-phase, suggesting that hUbc9 is involved in degradation of cyclins, as Ubc9 is in yeast (Masson et al., 1997).

The transcription of yeast DNA glycosylase genes MAG1, NTG1, and NTG2 is co-regulated with proteasomal genes and modulated by transcription factor Rpn4, a negative regulator of the proteosome (Jelinsky et al., 2000; Hanna \& Finley, 2007). Another BER DNA glycosylase, 
thymine-DNA glycosylase (TDG), binds SUMO-1 covalently and noncovalently (Takahashi et al., 2005). Covalent modification of TDG with SUMO-1 or SUMO-3 reduces its affinity for DNA (Hardeland et al., 2002b). The enzymatic properties of TDG change upon sumoylation; $\mathrm{G} \bullet \mathrm{T}$ mismatch processing is repressed, whereas $\mathrm{G} \bullet \mathrm{U}$ processing augments. TDG sumoylation facilitates its dissociation from AP sites, allowing for AP endonuclease entry (Hardeland et al., 2002b). Mechanistically, TDG changes conformation when it contacts DNA, binding tightly to mismatches; conjugation of SUMO-1 to the C-terminal domain of TDG induces another conformational change in the N-terminus of TDG so that it can dissociate from the AP sites (Steinacher \& Schar, 2005b). TDG sumoylation does not seem to affect polyubiquitination and degradation of TDG (Hardeland et al., 2007).

While TDG levels are highest during G2/M- and G1-phases of the cell-cycle but taper during S-phase, UNG2, a uracil-DNA glycosylase, is upregulated during S-phase (Hardeland et al., 2007). Thus, TDG and UNG2 play non-redundant, alternating roles. The UPS regulates these precise fluctuations in TDG and UNG2 protein levels; for example, treatment with the proteasomal inhibitor MG132 measurably increases TDG levels (Hardeland et al., 2007).

Interestingly, a key role of ubiquitination in BER is to modify the proteins that are not members of an active BER complex so that they may be rapidly degraded, which allows clearance of access for BER proteins. CHIP, an E3 enzyme, is responsible for turnover of BER proteins such as Xrcc1, which acts as a scaffold for directing assembly of BER complexes at sites of DNA damage, and Pol $\beta$ (Parsons et al., 2008b). Although CHIP appears to be the principal E3 in this process, other E3 enzymes may be involved as well. Phosphorylation of Xrcc1 by casein kinase 2 (CK2) appears to be necessary for efficient BER; this phosphorylation improves the stability of Xrcc1 by protecting it from ubiquitination (Parsons et al., 2010). In addition, Xrcc1 recruits JWA to sites of damage, and loss of JWA leads to Xrcc1 degradation by the UPS (Wang et al., 2009). Xrcc1 is also modified by SUMO1 (Gocke et al., 2005; Moschos \& Mo, 2006).

\section{Mismatch repair}

The mismatch repair (MMR) system corrects noncomplementary base pairs that escape the proofreading activity of DNA polymerases $\delta$ and $\varepsilon$ in DNA replication (Jiricny, 1998; Sharova, 2005b). The process begins with mispair recognition by the hMutSa complex, a heterodimer of hMSH2 and hMSH6, or by the complex hMutS $\beta$, a heterodimer of hMSH2 and hMSH3 (Modrich \& Lahue, 1996; Jiricny, 1998; Kolodner \& Marsischky, 1999). Another complex, hMutLa, a heterodimer of hMLH1and hPMS2, regulates the termination of mismatch-stimulated DNA excision (Li, 2008).

\subsection{Mismatch repair and the UPS}

The UPS is involved in post-transcriptional regulation of hMutSa protein expression (Humbert et al., 2002; Hernandez-Pigeon et al., 2004). Ubiquitination and degradation rates of hMSH2 and hMSH6 appear quite similar, suggesting that UPS-mediated proteolysis may maintain a constant ratio of these two proteins (Hernandez-Pigeon et al., 2004). While no strong correlation between total proteasomal activity and the degradation rate of hMutSa has been observed in vitro, low hMutSa expression in cells is a limiting factor for MMR and indicative of proteolytic activity of the UPS in MMR regulation (Ciechanover, 1994; Humbert et al., 2002; Hernandez-Pigeon et al., 2004). This process is regulated also by an 
atypical protein kinase $\mathrm{C} \zeta(\mathrm{PKC \zeta})$; this kinase increases hMutSa protein levels and the

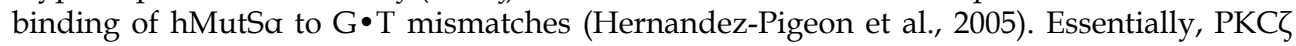
expression and ubiquitination of hMutSa proteins are inversely related, and PKC $\zeta$ kinase activity interferes in the UPS-mediated degradation of hMutSa (Hernandez-Pigeon et al., 2005). Collectively, these results support a model in which PKC $\zeta$ serves as a positive regulator for UPS-mediated MMR by directly interacting with the hMutSa complex. There is also evidence of hMutSa protein sumoylation, but the functional importance of this is unclear (Hernandez-Pigeon et al., 2005).

Human exonuclease I (hEXO1) complexes with hMutLa and functions in the excision step of MMR (Schmutte et al., 2001; Genschel et al., 2002). In response to DNA replication arrest, the isoform hEXO1b is polyubiquitinated and degraded, and phosphorylation of hEXO1b correlates with its UPS-mediated degradation (El-Shemerly et al., 2005).

\section{Double-strand break repair}

DNA double-strand breaks (DSBs) can be lethal to cells predominantly because the most important DSB repair process, non-homologous end joining (NHEJ), is error-prone, leaving mutations in the DNA following repair. Two possible repair processes that correct DSBs are homologous recombination (HR) and NHEJ. HR repair exchanges nucleotide sequences between two homologous chromosomes; this leads to error-free repair of DSB damage, preventing mutagenesis ( $\mathrm{Li}$ et al., 2000). During the initial stages of mammalian HR, the MRN complex, composed of Mre11-Rad50-Nbs1, recognizes and carries out initial processing of the broken DNA ends. Following DSB resection, single-stranded DNA ends are bound by Rad51, Rad52, and RPA (Zhao et al., 2007). Strand invasion and displacement to initiate repair synthesis from the homologous sequence are mediated by Rad51, Rad54, Brca1, and Brca2, and HR is completed upon DNA annealing and ligation (Li \& Heyer, 2008). NHEJ is a rapid, error-prone pathway that does not necessarily restore the sequence around the DSB, leading to local deletions and chromosomal translocations. NHEJ is the predominant form of DSB repair in mammalian cells because it occurs in the G0-, G1-, and early S-phases of the cell-cycle (before duplication of the DNA). The Ku70/Ku80 heterodimer detects the exposed ends of DNA DSBs in NHEJ and then recruits and forms a holoenzyme with DNA-dependent protein kinase (DNA-PK) to sense and to repair damaged DNA (Gottlieb \& Jackson, 1993; Downs \& Jackson, 2004). The MRN complex also influences NHEJ, and Xrcc4 and ligase IV complete the resealing reaction.

\subsection{Double-strand break repair and the UPS}

Crosslinking and chromatin immunoprecipitation studies reveal that subunits of the $26 \mathrm{~S}$ proteasome are recruited to DSB sites, suggesting that proteolysis takes place concurrent with DSB repair (Krogan et al., 2004). Both NHEJ and HR are affected by interaction with the proteasome, such as through DNA polymerase IV (Pol4) and Rad52, respectively (Tseng \& Tomkinson, 2002; Krogan et al., 2004). Rad52 forms multimeric ring foci, which are centers of recombination repair capable of processing multiple DNA lesions (West, 2003). Other HR proteins depend on the presence of Rad52 and its interaction with ssDNA regions in HR repair for their function (West, 2003). In yeast, one of the proteins associated with Rad52 is Sem1, a component of the yeast $19 \mathrm{~S}$ proteasome. In the absence of Rad52, recruitment of Sem1 to damaged DNA is reduced (Krogan et al., 2004). Moreover, knock-out of Sem1 in yeast strains capable of only HR or NHEJ, but not both, results in impaired cell 
growth. Therefore, Sem1 and the proteasome are crucial for HR DSB repair (Krogan et al., 2004). The human homolog of Sem1, Deleted in Split hand/Split foot 1 (DSS1), is a part of the human 19S proteasome and involved in HR through interaction with Brca2 (Marston et al., 1999). Just as knock-out of Brca2 increases dependence of HR on mammalian Rad52 (West, 2003), depletion of DSS1 in human cells significantly reduces HR activity, while treatment with proteasome inhibitors corresponds to a smaller decrease in HR (Kristensen et al., 2010). Thus, it is likely that DSS1 engages in functions in HR other than strictly proteolysis (Kristensen et al., 2010).

DSS1 and Brca2 interact with Rpn3 and Rpn7, though the Brca2/Rpn7 interaction does not depend on DSS1 (Gudmundsdottir et al., 2007). On the contrary, it is Brca2 that secures the presence of the proteasome close to DNA repair machinery. Upon treatment of an ES cell line with the proteasome inhibitor epoxomicin, Gudmundsdottir and colleagues observed a shift in the repair of repetitive elements from the error-free gene conversion pathway to the error-prone single-strand annealing pathway. This suggests that the proteasome plays a functional role in support of HR as a repair mechanism of DSBs (Gudmundsdottir et al., 2007).

As mentioned previously, knock-out of different proteasomal subunits or proteosome inhibition by small molecules interferes with both HR and NHEJ in yeast (Krogan et al., 2004); in higher eukaryotes, association of NHEJ and proteosome appears to be less obligatory. Here, proteasome inhibitors MG132 and LC reduce HR-dependent DSB repair but only marginally affect NHEJ-mediated repair of an artificial substrate (Murakawa et al., 2007). MG132 treatment of Ku70-deficient chicken DT40 cells, which are impaired in NHEJ but not in HR, negatively affects the repair kinetics of ionizing radiation-induced DSBs. However, MG132 treatment of Rad54-deficient chicken DT40 cells, impaired in HR but not in NHEJ, does not delay DSB repair. Ionizing radiation-induced Brca1 and Rad51 foci formation in HeLa cells is reduced upon treatment with MG132. Therefore, it appears as if the proteasome functions at an early step of HR, prior to formation of the Brca2-DSS1 complex (Murakawa et al., 2007).

Brca1 contains a RING domain, which is generally associated with ubiquitin-protein ligase activity (Starita \& Parvin, 2003). Human C-terminal binding protein interacting protein (CtIP), which regulates DSB resection and efficient HR, is ubiquitinated when it associates with chromatin following DNA damage. This ubiquitination of CtIP is catalyzed by Brca1 and is not a degradation signal (Yu et al., 2006; Sartori et al., 2007). Brca1 dimerizes with Bard1 to elicit higher ubiquitin-protein ligase activity than either Brca1 or Bard1 alone (Hashizume et al., 2001; Xia et al., 2003). These two proteins appear to stabilize one another in vivo, suggesting that each does not participate in the degradation of the other (Hashizume et al., 2001; Xia et al., 2003). Brca1/Bard1 assemble polyubiquitin chain linkages through non-K48 residues, mostly through $\mathrm{K} 63$, indicative of non-proteolytic function (Chen et al., 2002). The Brca1/Bard1 complex is capable of autoubiquitination in vitro and in vivo, and it also mediates monoubiquitination of histone H2A/H2AX in vitro (Chen et al., 2002). At a higher level of complexity, Brca1/Bard1, Rap80, which has two domains that bind K63linked ubiquitin chains, the DUB Brcc36, and Abraxas form a complex that localizes to damaged DNA (Wang \& Elledge, 2007). Ubc13, an E2 enzyme, and Rnf8, a Ubc13-associated E3 enzyme, which together catalyze K63-linked ubiquitin chains at DSBs, are both required for Rap80 and Abraxas foci formation induced by ionizing radiation (Huen et al., 2007; Kolas et al., 2007; Wang \& Elledge, 2007). The interaction between Rap80 and Abraxas localizes Brca1 and the DUB Brcc36 to ionizing radiation-induced foci (Wang \& Elledge, 2007). 
In conducting studies revolving around the sensitivity of Ubc13-deficient cells to DNAdamaging agents, Zhao and co-workers discovered a link between Ubc13 and HR in higher eukaryotes. Mammalian cells depleted of Ubc13 demonstrate defective HR following ionizing radiation (Zhao et al., 2007). This observation corresponds with impaired recruitment of Rad51 to DSBs, reduced Brca1 ubiquitin-protein ligase activity and foci formation, and decreased accumulation of RPA single-strand binding protein at DNA lesions. NHEJ, however, appears to function normally in Ubc13 null cells. The role of Ubc13 in HR does not appear to involve PCNA ubiquitination, thereby distinguishing the role of Ubc13 in HR from its activities in post-replication repair (PRR). Nevertheless, the mechanism of Ubc13-promoted DSB resection requires further investigation (Zhao et al., 2007).

The E3 ubiquitin-protein ligase, Rnf8, a modulator of the DNA damage response, mediates histone ubiquitination and allows DSB-flanking chromatin to accumulate additional DNA damage regulators (Huen et al., 2007; Kolas et al., 2007; Mailand et al., 2007; Wang \& Elledge, 2007; Doil et al., 2009). In particular, Rnf8 is required for accumulation of 53BP1 and Brca1 following ionizing radiation (Huen et al., 2007; Kolas et al., 2007; Mailand et al., 2007; Sakasai \& Tibbetts, 2008). Following UV illumination, recruitment of 53BP1 partially depends on Ubc13 and Rnf8, and 53BP1 recruitment is suppressed upon proteasomal inhibition (Sakasai \& Tibbetts, 2008). Importantly, 53BP1-deficient cells exhibit defects in NHEJ (Nakamura et al., 2006). Rnf8 is the first E3 to assemble at DSBs and allows for the recruitment of another E3 ligase, Rnf168, which has two ubiquitin-binding domains. Rnf168 appears to increase K63-linked ubiquitination at DSBs necessary to retain 53BP1 and Brca1 (Doil et al., 2009). Stewart and co-workers identified Rnf168 as the gene mutated in RIDDLE Syndrome (Stewart et al., 2009), a disorder characterized in part by radiosensitivity and immunodeficiency. Cells derived from a RIDDLE patient fail to localize 53BP1 to DSBs (Stewart et al., 2007). Accordingly, these cells display decreased Brca1 foci formation, hypersensitivity to ionizing radiation, and irregular cell-cycle checkpoints (Stewart et al., 2007; Stewart et al., 2009).

With regard to UBLs, SUMO-1 is the most frequently involved in DSB repair; it forms stable complexes with Rad51, Rad52, and Rad51/Rad52 in co-immunoprecipitation experiments (Shen et al., 1996; Li et al., 2000). The role of SUMO-1 in HR appears to be inhibitory, as overexpression of SUMO-1 has been shown to measurably decrease radioresistance and bidirectional gene conversion tracts in mammalian cells (Li et al., 2000). Sumoylation of Rad52 is observed infrequently unless this modification of Rad52 is induced in a cell cycleand lesion-specific fashion (Ohuchi et al., 2008). In yeast, Rad52 sumoylation appears to be triggered specifically by interactions with Rad50, Mre11 and Xrs2 (but not Rad51), members of the yeast homolog of the MRN complex, the MRX complex (Sacher et al., 2006; Ohuchi et al., 2008). There is conflicting evidence pertaining to the residues required for Rad52 sumoylation, but self-association of Rad52 appears important for its sumoylation. Essentially, sumoylation of Rad52 appears to preserve Rad52 activity and to inhibit rapid degradation of the protein (Sacher et al., 2006).

Two of the key NHEJ enzymes, Ku70 and Ku80, are susceptible to ubiquitination (Gama et al., 2006). Ku70 and Ku 80 are degraded by the proteasome, and MG132 delays proteolysis of these proteins (Postow et al., 2008; Enokido et al., 2010). Ubiquitinated Ku70 in human cells has been detected in the absence of proteasome inhibitors, indicating that this modification may not always serve as a degradation signal for Ku70; yet, apoptotic stress does upregulate degradative Ku70 ubiquitination (Gama et al., 2006). Ku70 and Ku80 
stabilize one another, but ubiquitinated Ku70 appears to inhibit Ku70/Ku80 complex formation (Gama et al., 2006). Ku80 is polyubiquitinated when bound to DSBs in Xenopus laevis egg extracts, and this K48-linked polyubiquitination is related to removal of Ku80 from DNA (Postow et al., 2008). However, polyubiquitination-induced removal of Ku80 from DSBs is not required for the completion of NHEJ (Postow et al., 2008). In yeast, aberrant expression of key proteosome regulating transcription factor Rpn4 appears to hinder NHEJ but not HR (Ju et al., 2010). When proteosomal degradation of Rpn4 itself is inhibited, the expression levels of Ku70, Ku80, and Mre11 are decreased, as well as the accumulation of Ku70 at DSBs (Ju et al., 2010).

Ubiquitination and levels of monoubiquitinated Xrcc4 increase upon etoposide-induced DNA damage (Foster et al., 2006). Xrcc4, however, is a stable protein, and treatment with proteasome inhibitors does not correlate with Xrcc4 accumulation, suggesting that this type of Xrcc4 modification serves a non-proteolytic function. This enzyme also stabilizes ligase IV, whose half-life also increases upon treatment with proteasome inhibitors (Foster et al., 2006). Human Xrcc4 is also sumoylated in vitro and in vivo (Yurchenko et al., 2006). This modification regulates Xrcc4 localization; a non-sumoylated mutated Xrcc4 protein accumulates in the cytoplasm rather than in the nucleus (Yurchenko et al., 2006). This mutant protein causes radiosensitivity, but fusion of SUMO to its C-terminus leads to nuclear Xrcc4 localization and radiation resistance of cells with this genotype (Yurchenko et al., 2006).

\section{Post-replication repair}

Post-replication repair (PRR), also known as DNA damage tolerance or damage bypass, is a process that fills gaps formed in newly synthesized single-stranded DNA. This type of repair is essential for avoiding unrepaired DSBs, such as those that result from the prolonged stalling of DNA replication forks (Podlaska et al., 2003; Zhuang et al., 2008). PRR operates by either an error-free or an error-prone mechanism. The error-free/damage avoidance pathway involves HR or template switching to the undamaged sister chromatid (Lee \& Myung, 2008; Ulrich, 2009). The error-prone method, referred to as DNA translesion

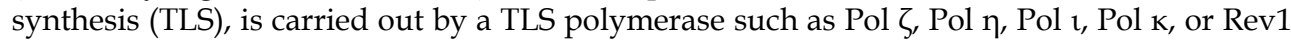
(Prakash et al., 2005). Rad6, an E2 enzyme, and Rad18, a DNA-binding protein, form a complex that governs PRR and is responsible for PCNA modification, a crucial event in this DNA repair pathway (Hoege et al., 2002; McIntyre et al., 2006).

\subsection{Post-replication repair and the UPS}

Proteasome inhibitors have been shown to disrupt TLS in cancer cells by delaying cisplatin and UV-induced translesion reactions (Takezawa et al., 2008). Studies of defective $20 \mathrm{~S}$ proteasomal activity in yeast strains have revealed important relationships between the UPS and PRR. The Ump1 proteasomal maturase is required for processing of the $\beta$-subunits and proper assembly of the $20 \mathrm{~S}$ proteasome (Ramos et al., 1998). Deletion of Ump1 or of the genes encoding the $\beta 2$ - and $\beta 5$-subunits of the 20S proteasome, Pup1 and Pre2, respectively, correlates with an increase in UV-sensitivity and spontaneous mutagenesis. Importantly, this phenotype is characteristic of yeast strains with defects in PRR, and Podlaska and colleagues have determined that these genes are members of the Rad6/Rad18 epistasis group (Podlaska et al., 2003). This spontaneous mutator phenotype has been verified to be primarily PRR-based and unrelated to the HR and NER pathways (McIntyre et al., 2006). 
Knock-out of Rev3, which encodes the catalytic subunit of Pol $\zeta$, in an Ump1-deficient yeast strain correlates with a dramatic decrease in the frequency of UV-induced and spontaneous mutations, thereby suggesting that Ump1 may serve as a negative regulator of Rev3 (Podlaska et al., 2003; McIntyre et al., 2006; Wiltrout \& Walker, 2011). In contrast, the presence of Rad30, which encodes Pol $\eta$, in an Ump1-deficient background is associated with increased UV-sensitivity but a decrease in the frequency of spontaneous mutations (Podlaska et al., 2003; McIntyre et al., 2006). Taken together, these results suggest that Rev3 and Rad30 are epistatic to Ump1 and that mutations caused by proteasomal defects depend upon both Pol $\zeta$ and Pol $\eta$ (Podlaska et al., 2003; McIntyre et al., 2006). Rad30 is a short-lived protein post-translationally regulated by the UPS (Skoneczna et al., 2007). Its degradation depends on the Skp1/Cullin/F-box E3 enzyme complex and the Ufo1 F-box protein (Skoneczna et al., 2007). Rev1 is also a relatively short-lived protein but has a longer half-life during G2/M-phases than G1-phase, potentially implicating proteasomal regulation. In support of this idea, Rev1 levels are elevated upon treatment with proteasome inhibitors or in an Ump1-deficient background (Wiltrout \& Walker, 2011).

Ubiquitin is essential for the regulation, localization, and stability of Rad18 PRR protein (Ulrich, 2009). In response to DNA damage, Rad18 autoubiquitination indirectly regulates PRR by balancing levels of unmodified Rad18 in the nucleus and monoubiquitinated Rad18 in the cytoplasm (Miyase et al., 2005). Polyubiquitinated Rad18 is not present under normal conditions, potentially because it is subject to rapid degradation. However, polyubiquitinated Rad18 may be detected upon treatment with proteasome inhibitors or in an in vitro system consisting of Rad18, one E1 enzyme, Rad6, and ubiquitin (Miyase et al., 2005).

Rad18 also influences PCNA monoubiquitination following DNA damage (Hoege et al., 2002; Stelter \& Ulrich, 2003; Kannouche et al., 2004). Monoubiquitinated PCNA is thought to promote the error-prone TLS pathway, while polyubiquitinated PCNA may regulate the error-free damage avoidance pathway (Hoege et al., 2002; Stelter \& Ulrich, 2003; Kannouche et al., 2004; Watanabe et al., 2004). Monoubiquitinated PCNA is thought to facilitate targeting of $\mathrm{Pol} \eta$ to DNA damage sites and is required for the replacement of stalled Pol $\delta$ by Pol $\eta$ (Kannouche et al., 2004; Watanabe et al., 2004; Zhuang et al., 2008). In response to DNA damage, Pol $\eta$ and Pol 1 also noncovalently interact with ubiquitin and monoubiquitinated PCNA (Bienko et al., 2005; Plosky et al., 2006). Pol $\eta$ and Pol ı mutants lacking the ability to bind ubiquitin demonstrate downregulated levels of DNA damageinduced replication foci; this suggests that the polymerase-ubiquitin interaction may be an important component in the recruitment of TLS polymerases to stalled replication forks (Plosky et al., 2006). Ubiquitinated PCNA also substantially activates Pol $\eta$ and Rev1 in vitro

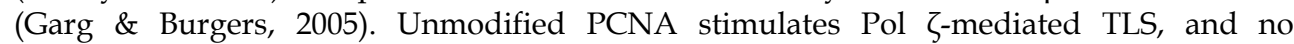
significant differences in this type of TLS are observed upon substitution of unmodified PCNA with ubiquitinated PCNA (Garg \& Burgers, 2005; Garg et al., 2005). Thus, ubiquitinated PCNA has different functional interactions with the various TLS polymerases. Importantly, it appears as if ubiquitination of, rather than sumoylation of, PCNA contributes to the observed spontaneous mutator phenotype associated with proteasomal defects (McIntyre et al., 2006). An important role for sumoylation of PCNA seems to be in preventing unscheduled HR during S-phase (Papouli et al., 2005; Pfander et al., 2005). Nevertheless, recent studies suggest that PCNA sumoylation may be required for the stimulation of TLS in addition to the presence of monoubiquitinated PCNA (Halas et al., 2011). In the case of PCNA, SUMO and ubiquitin appear to cooperatively rather than 
competitively coordinate the choice in DNA repair pathways of replication lesions (Plosky et al., 2006).

\section{Fanconi anemia}

Fanconi anemia (FA) is a rare autosomal recessive and X-linked genetic disorder characterized in part by congenital deformities, bone marrow failure, and elevated risk of cancer. FA is associated with hypersensitivity to DNA crosslinking agents, and treatment of FA cells with such agents (mitomycin C, for example) leads to chromosomal instability and cell death (Heinrich et al., 2000). 13 FA complementation groups have been identified (FANCA, B, C, D1, D2, E, F, G, I, J, L, M, and N), and disruption of any one of the genes named after these complementation groups causes FA. Proposed roles for the FA pathway include involvement in circumventing stalled replication forks, HR, TLS, enzymatic DNA processing, and cell-cycle regulation (Kennedy \& D'Andrea, 2005; Pang \& Andreassen, 2009; Kratz et al., 2010).

\subsection{Fanconi anemia and DNA repair}

At least 8 of the FA complementation groups (FANCA, B, C, E, F, G, L, and M) and two associated proteins, FAAP24 and FAAP100, form an E3 enzyme complex required for monoubiquitination of FANCD2 (Ciccia et al., 2007; Ling et al., 2007). Loss of any subunit of this FA core complex negatively alters complex formation and prevents FANCD2 monoubiquitination (Huang \& D'andrea, 2006). Specifically, monoubiquitination of FANCD2 occurs at K561 during S-phase during normal cell-cycle progression as well as following DNA damage (Kennedy \& D'Andrea, 2005). The latter event is linked to FANCD2 localization to chromatin and colocalization with other DNA damage signalling proteins such as FANCD1, Brca2, Rad51, Nbs1, and PCNA (Kennedy \& D'Andrea, 2005; Nijman et al., 2005). FANCL is capable of autoubiquitination in vitro and is required for monoubiquitination of FANCD2 and its relocation to damage-associated nuclear foci, suggesting that FANCL is the catalytic component of the FA core complex (Meetei et al., 2003; Huang \& D'andrea, 2006). Brca1 has the potential to serve as an E3 enzyme for FANCD2 in vitro, but genetic evidence hints that Brca1 is not required for FANCD2 monoubiquitination (Vandenberg et al., 2003). Instead, Brca1 may modulate monoubiquitination of FANCD2 or the stability of the modified protein (Meetei et al., 2003). UBE2T, which directly binds FANCL, is the E2 enzyme involved in monoubiquitination of FANCD2 (Machida et al., 2006). UBE2T engages in a negative feedback loop, commencing self-inactivation by automonoubiquitination in vivo (Machida et al., 2006). RPA1 and ATR are required for efficient FANCD2 monoubiquitination, and ATM is not necessary in this process (Andreassen et al., 2004). Similarly, silencing of ATR, but not of ATM, suppresses FANCD2 foci formation following exposure of cells to DNA crosslinking agents (Andreassen et al., 2004). As with PCNA, the DUB Usp1 associates with and regulates monoubiquitination of FANCD2, and Usp1 inhibition increases FANCD2 monoubiquitination (Nijman et al., 2005).

FANCD2 and FANCI share sequence homology (Smogorzewska et al., 2007). Small interfering RNAs (siRNAs) directed against FANCD2, FANCI, and FANCA suppress HR, suggesting a role of these proteins in the DSB repair pathway. Like FANCD2, FANCI is ubiquitinated following DNA damage or during normal S-phase. These two enzymes form a complex, known as ID, which dictates FANCD2 localization in damage-associated nuclear 
foci. FANCD2 and FANCI are interdependent in that ubiquitin modification of each protein is dependent upon ubiquitin modification of the other (Smogorzewska et al., 2007). FANCI also restricts monoubiquitination of FANCD2 to the correct lysine residue in vivo (Alpi et al., 2008). FANCD2-ubiquitin and FANCD2-histone H2B fusion proteins harbouring an arginine substitution to remove the monoubiquitin site of FANCD2 have been shown to colocalize to chromatin and to reverse DNA-crosslink hypersensitivity of FANCD2-deficient cells (Matsushita et al., 2005). However, these fusion proteins do not complement FANCC-, FANCG-, or FANCL-deficient cells, suggesting that the members of the FA core complex play roles outside that of monoubiquitination and chromatin targeting of FANCD2 (Matsushita et al., 2005). The link between monoubiquitination of FANCD2/FANCI and recruitment of the ID complex to chromatin remains unclear (Al-Hakim et al., 2010). Recent findings surrounding the FANCD2-associated nuclease KIAA1018/FAN1 provide valuable information regarding the functional importance of ID complex ubiquitination. FAN1 is a conserved protein with an N-terminal ubiquitin-binding zinc finger (UBZ) and a C-terminal nuclease domain (Kratz et al., 2010; Liu et al., 2010; MacKay et al., 2010; Smogorzewska et al., 2010). FAN1 interacts with FANCD2 and FANCI, and loss of FAN1 is associated with hypersensitivity to and defective repair of intrastrand crosslinks. The UBZ of FAN1 targets the protein to damage-induced nuclear foci since deletion of the UBZ prevents FAN1 from accumulating at sites of damage (Kratz et al., 2010; Liu et al., 2010; MacKay et al., 2010; Smogorzewska et al., 2010). Importantly, this recruitment of FAN1 is dependent upon interaction of its UBZ domain with monoubiquitinated FANCD2. Although the mechanism of FAN1 is still being elucidated, it will be interesting to determine whether other factors which also recognize ID complex monoubiquitination are recruited to sites of damage by crosslinking agents (Al-Hakim et al., 2010).

\section{Proteasome inhibitors and DNA repair}

Proteasome inhibitors include synthetic molecules and natural products (Groll et al., 2009). Most small molecule proteasome inhibitors are peptide derivatives that bind to the proteolytic active sites of the 20 S proteasome (Huang \& Chen, 2009). Specifically, bortezomib (PS-341, Velcade) is a dipeptidyl boric acid that selectively and reversibly inhibits the $\beta 5$-subunit of the 20S with high affinity (Berkers et al., 2005). Clinically, bortezomib administration results in tumor shrinkage through events such as cellular growth arrest, increased apoptosis, and decreased angiogenesis (Russo et al., 2007; Gilardini et al., 2008). The mechanisms by which bortezomib exerts its effects, however, remain controversial. It has been shown that bortezomib stabilizes p21, p27, p53, proapoptotic proteins such as Bid and Bax, and the transcription factor Myc (McConkey \& Zhu, 2008; Orlowski \& Kuhn, 2008). Inhibition of NF-kB and of anti-apoptotic proteins, generation of reactive oxygen species (ROS), and increases in endoplasmic reticulum (ER) stress have also been implicated by some and repudiated by others as potential bortezomib-stimulated outcomes (Chen et al., 2010). Nevertheless, although the exact mechanisms of bortezomibinduced cell death remain inconclusive, current research hints at a role of DNA repair in this process.

Bortezomib has been shown to enhance the DNA damage response. In a genome-wide siRNA screen to identify genetic components linked to bortezomib-induced cell death, knockdown of proteins responsible for HR was found to be protective against cell death 
(Chen et al., 2010). Bortezomib treatment leads to stabilization of Rad51, upregulation of ATM-dependant phosphorylation of H2AFX, CHK2, SMC1A, and TP53 and of ATRdependent phosphorylation of CHK1, as well as increased monoubiquitination of FANCD2 (Chen et al., 2010). Bortezomib has also been shown to inhibit basal and DNA damageinduced monoubiquitination of FANCD2 but not of PCNA (Jacquemont \& Taniguchi, 2007). A phase 3 clinical trial of bortezomib with melphalan and prednisone, the standard treatment of multiple myeloma patients, is currently ongoing with patients who cannot receive high-dose therapy (Chen et al., 2005; San Miguel et al., 2008). HR and FA are thought to be required for resistance to melphalan, a chemotherapeutic DNA alkylating agent, and bortezomib plus melphalan and prednisone produces outcomes greater than melphalanprednisone alone (Wang et al., 2001; Chen et al., 2005). Since bortezomib appears to interfere with DNA-damage signaling, sensitization of cancer cells to melphalan and prednisone coud be due to the influence of the proteasome on one or more DNA repair pathway(s). Treatment of cells first with ionizing radiation or DNA crosslinking agents and secondly with bortezomib delays formation of phospho-ATM, 53BP1, Nbs1, and Brca1 foci and inhibits formation of FANCD2 and Rad51 foci. However, $\gamma-\mathrm{H} 2 \mathrm{AX}, \mathrm{MDC} 1$, and RPA foci are unaffected by these treatments, suggesting that early DNA damage signaling remains intact in these cells. This and similar results found using the proteasome inhibitors MG132 and epoxomicin (Jacquemont \& Taniguchi, 2007; Takeshita et al., 2009) again suggest the requirement for UPS in DNA repair progression.

\section{Conclusion}

Here, we have summarized some of the current understanding of the relation of UPS to NER, BER, MMR, DSB, PRR, and FA repair. However, the influence of the UPS on DNA repair is not restricted to these repair mechanisms, as evidence suggests that the UPS also affects pathways beyond the scope of this review, such as direct repair by MGMT (O6methylguanine-DNA methyltransferase) (Vlachostergios et al., 2009a). Much evidence shows that the UPS is a potent regulator of repair following DNA damage. It will no doubt be interesting and beneficial to expand our knowledge of the UPS and DNA repair by using proteasome inhibitors such as bortezomib in conjunction with different chemotherapeutic and irradiation treatments.

The obligatory cooperation between DNA repair and UPS is clearly preserved throughout eukaryotic evolution (Daulny \& Tansey, 2009); upon consideration, this is a very logical example of the interdependence of seemingly disparate biological systems. Sequential enzymatic activity is a hallmark of well-regulated biological processes. In DNA repair, it appears in many cases that replacement of one enzyme with another depends on its tightly regulated proteolysis or other UPS-mediated modification (Hardeland et al., 2002a; Steinacher \& Schar, 2005a; Parsons et al., 2008a). The UPS has the necessary degree of control to execute the proteolysis in a manner required, enabling the repair processes to advance through different stages. A well-orchestrated activity of the two processes suggests that DNA repair and the UPS have co-evolved to provide living organisms with a way to cope with environmental DNA injuries. Increasingly complex UPS-mediated regulation of multifunctional repair enzymes such as PCNA, coinciding with evolution of higher eukaryotes, further supports this notion.

It is interesting to note that DNA repair in prokaryotes, where there is no proteasome system, is regulated predominantly at the transcriptional level (Friedberg, 1996). This 
regulation often involves the removal of a single protein (a transcriptional repressor), which allows for a particular operon to be expressed. In eukaryotes, while there are a few DNA repair proteins that are transcriptionally regulated (for example, PCNA and DNA polymerase $\beta$ ), most DNA repair is regulated at the level of post-translational modifications such as phosphorylation, acetylation, protein complex formation, as well as monoubiquitination, polyubiquitination, sumoylation, etc. (Vlachostergios et al., 2009b; Vlachostergios et al., 2009a). The removal of specific proteins is needed for the DNA repair process progression in eukaryotic cells, but this removal in eukaryotes is more complex than the repressor system of DNA repair regulation prokaryotes - it requires the complex UPS to regulate protein accumulation and turnover (Motegi et al., 2009). It is possible that the expansion of the eukaryotic genome to contain large numbers genes on several chromosomes made it necessary for proteasome complexes to co-exist and control DNA repair protein quantities at the level of protein degradation.

\section{Acknowledgments}

The authors would like to thank Jay Nathwani for his careful reading of and helpful comments regarding this manuscript. This work was supported by NIH grant R01EB002100 and DOE grant DE-SC0001271.

\section{References}

Al-Hakim, A.; Escribano-Diaz, C.; Landry, M.C.; O'Donnell, L.; Panier, S.; Szilard, R.K. \& Durocher, D. (2010). The ubiquitous role of ubiquitin in the DNA damage response. DNA Repair (Amst), Vo.9, No.12, pp. 1229-1240

Alpi, A.F.; Pace, P.E.; Babu, M.M. \& Patel, K.J. (2008). Mechanistic insight into site-restricted monoubiquitination of FANCD2 by Ube2t, FANCL, and FANCI. Molecular Cell, Vo.32, No.6, pp. 767-777

Andreassen, P.R.; D'Andrea, A.D. \& Taniguchi, T. (2004). ATR couples FANCD2 monoubiquitination to the DNA-damage response. Genes and Development, Vo.18, No.16, pp. 1958-1963

Arrigo, A.P.; Tanaka, K.; Goldberg, A.L. \& Welch, W.J. (1988). Identity of the 195 'prosome' particle with the large multifunctional protease complex of mammalian cells (the proteasome). Nature, Vo.331, No.6152, pp. 192-194

Bergink, S.; Jaspers, N.G. \& Vermeulen, W. (2007). Regulation of UV-induced DNA damage response by ubiquitylation. DNA Repair (Amst), Vo.6, No.9, pp. 1231-1242

Bergink, S.; Salomons, F.A.; Hoogstraten, D.; Groothuis, T.A.; de Waard, H.; Wu, J.; Yuan, L.; Citterio, E.; Houtsmuller, A.B.; Neefjes, J.; Hoeijmakers, J.H.; Vermeulen, W. \& Dantuma, N.P. (2006). DNA damage triggers nucleotide excision repair-dependent monoubiquitylation of histone H2A. Genes and Development, Vo.20, No.10, pp. 13431352

Bergoglio, V. \& Magnaldo, T. (2006). Nucleotide excision repair and related human diseases. Genome Dyn, Vo.1, pp. 35-52

Berkers, C.R.; Verdoes, M.; Lichtman, E.; Fiebiger, E.; Kessler, B.M.; Anderson, K.C.; Ploegh, H.L.; Ovaa, H. \& Galardy, P.J. (2005). Activity probe for in vivo profiling of the specificity of proteasome inhibitor bortezomib. Nat Methods, Vo.2, No.5, pp. 357-362 
Bienko, M.; Green, C.M.; Crosetto, N.; Rudolf, F.; Zapart, G.; Coull, B.; Kannouche, P.; Wider, G.; Peter, M.; Lehmann, A.R.; Hofmann, K. \& Dikic, I. (2005). Ubiquitinbinding domains in Y-family polymerases regulate translesion synthesis. Science, Vo.310, No.5755, pp. 1821-1824

Chen, A.; Kleiman, F.E.; Manley, J.L.; Ouchi, T. \& Pan, Z.Q. (2002). Autoubiquitination of the BRCA1*BARD1 RING ubiquitin ligase. J Biol Chem, Vo.277, No.24, pp. 22085-22092

Chen, L. \& Chen, J. (2003). MDM2-ARF complex regulates p53 sumoylation. Oncogene, Vo.22, No.34, pp. 5348-5357

Chen, L.; Shinde, U.; Ortolan, T.G. \& Madura, K. (2001). Ubiquitin-associated (UBA) domains in Rad23 bind ubiquitin and promote inhibition of multi-ubiquitin chain assembly. EMBO Rep, Vo.2, No.10, pp. 933-938

Chen, Q.; Van der Sluis, P.C.; Boulware, D.; Hazlehurst, L.A. \& Dalton, W.S. (2005). The FA/BRCA pathway is involved in melphalan-induced DNA interstrand cross-link repair and accounts for melphalan resistance in multiple myeloma cells. Blood, Vo.106, No.2, pp. 698-705

Chen, S.Q.; Blank, J.L.; Peters, T.; Liu, X.Z.J.; Rappoli, D.M.; Pickard, M.D.; Menon, S.; Yu, J.; Driscoll, D.L.; Lingaraj, T.; Burkhardt, A.L.; Chen, W.; Garcia, K.; Sappal, D.S.; Gray, J.; Hales, P.; Leroy, P.J.; Ringeling, J.; Rabino, C.; Spelman, J.J.; Morgenstern, J.P. \& Lightcap, E.S. (2010). Genome-Wide siRNA Screen for Modulators of Cell Death Induced by Proteasome Inhibitor Bortezomib. Cancer Research, Vo.70, No.11, pp. $4318-4326$

Chen, X.; Ruggiero, C. \& Li, S. (2007). Yeast Rpb9 plays an important role in ubiquitylation and degradation of Rpb1 in response to UV-induced DNA damage. Molecular and Cellular Biology, Vo.27, No.13, pp. 4617-4625

Chen, Z.J. \& Sun, L.J. (2009). Nonproteolytic functions of ubiquitin in cell signaling. Molecular Cell, Vo.33, No.3, pp. 275-286

Ciccia, A.; Ling, C.; Coulthard, R.; Yan, Z.; Xue, Y.; Meetei, A.R.; Laghmani el, H.; Joenje, H.; McDonald, N.; de Winter, J.P.; Wang, W. \& West, S.C. (2007). Identification of FAAP24, a Fanconi anemia core complex protein that interacts with FANCM. Molecular Cell, Vo.25, No.3, pp. 331-343

Ciechanover, A. (1994). The ubiquitin-proteasome proteolytic pathway. Cell, Vo.79, No.1, pp. $13-21$

Ciechanover, A.; Elias, S.; Heller, H.; Ferber, S. \& Hershko, A. (1980a). Characterization of the heat-stable polypeptide of the ATP-dependent proteolytic system from reticulocytes. Journal of Biological Chemistry, Vo.255, No.16, pp. 7525-7528

Ciechanover, A.; Heller, H.; Elias, S.; Haas, A.L. \& Hershko, A. (1980b). Atp-Dependent Conjugation of Reticulocyte Proteins with the Polypeptide Required for ProteinDegradation. Proceedings of the National Academy of Sciences of the United States of America-Biological Sciences, Vo.77, No.3, pp. 1365-1368

Ciechanover, A.; Hod, Y. \& Hershko, A. (1978). Heat-Stable Polypeptide Component of an Atp-Dependent Proteolytic System from Reticulocytes. Biochemical and Biophysical Research Communications, Vo.81, No.4, pp. 1100-1105

Coutts, A.S.; Adams, C.J. \& La Thangue, N.B. (2009). p53 ubiquitination by Mdm2: A never ending tail? DNA Repair, Vo.8, No.4, pp. 483-490

Dahlmann, B. (2007). Role of proteasomes in disease. Bmc Biochemistry, Vo.8, pp. - 
Dalhus, B.; Laerdahl, J.K.; Backe, P.H. \& Bjoras, M. (2009). DNA base repair--recognition and initiation of catalysis. FEMS Microbiology Reviews, Vo.33, No.6, pp. 1044-1078

Dantuma, N.P.; Heinen, C. \& Hoogstraten, D. (2009). The ubiquitin receptor Rad23: At the crossroads of nucleotide excision repair and proteasomal degradation. DNA Repair, Vo.8, No.4, pp. 449-460

Daulny, A. \& Tansey, W.P. (2009). Damage control: DNA repair, transcription, and the ubiquitin-proteasome system. DNA Repair, Vo.8, No.4, pp. 444-448

Doil, C.; Mailand, N.; Bekker-Jensen, S.; Menard, P.; Larsen, D.H.; Pepperkok, R.; Ellenberg, J.; Panier, S.; Durocher, D.; Bartek, J.; Lukas, J. \& Lukas, C. (2009). RNF168 binds and amplifies ubiquitin conjugates on damaged chromosomes to allow accumulation of repair proteins. Cell, Vo.136, No.3, pp. 435-446

Downs, J.A. \& Jackson, S.P. (2004). A means to a DNA end: the many roles of Ku. Nature reviews. Molecular cell biology, Vo.5, No.5, pp. 367-378

Drexler, H.C. (1997). Activation of the cell death program by inhibition of proteasome function. Proceedings of the National Academy of Sciences of the United States of America, Vo.94, No.3, pp. 855-860

El-Shemerly, M.; Janscak, P.; Hess, D.; Jiricny, J. \& Ferrari, S. (2005). Degradation of human exonuclease $1 \mathrm{~b}$ upon DNA synthesis inhibition. Cancer Research, Vo.65, No.9, pp. 3604-3609

Enokido, Y.; Tamura, T.; Ito, H.; Arumughan, A.; Komuro, A.; Shiwaku, H.; Sone, M.; Foulle, R.; Sawada, H.; Ishiguro, H.; Ono, T.; Murata, M.; Kanazawa, I.; Tomilin, N.; Tagawa, K.; Wanker, E.E. \& Okazawa, H. (2010). Mutant huntingtin impairs Ku70mediated DNA repair. J Cell Biol, Vo.189, No.3, pp. 425-443

Finley, D. (2009). Recognition and Processing of Ubiquitin-Protein Conjugates by the Proteasome. Annual Review of Biochemistry, Vo.78, pp. 477-513

Fishbain, S.; Prakash, S.; Herrig, A.; Elsasser, S. \& Matouschek, A. (2011). Rad23 escapes degradation because it lacks a proteasome initiation region. Nat Commun, Vo.2, pp. 192

Foster, R.E.; Nnakwe, C.; Woo, L. \& Frank, K.M. (2006). Monoubiquitination of the nonhomologous end joining protein XRCC4. Biochemical and Biophysical Research Communications, Vo.341, No.1, pp. 175-183

Friedberg, E.C. (1996). Relationships between DNA repair and transcription. Annu Rev Biochem, Vo.65, pp. 15-42

Gama, V.; Yoshida, T.; Gomez, J.A.; Basile, D.P.; Mayo, L.D.; Haas, A.L. \& Matsuyama, S. (2006). Involvement of the ubiquitin pathway in decreasing Ku70 levels in response to drug-induced apoptosis. Experimental Cell Research, Vo.312, No.4, pp. 488-499

Garg, P. \& Burgers, P.M. (2005). Ubiquitinated proliferating cell nuclear antigen activates translesion DNA polymerases eta and REV1. Proceedings of the National Academy of Sciences of the United States of America, Vo.102, No.51, pp. 18361-18366

Garg, P.; Stith, C.M.; Majka, J. \& Burgers, P.M. (2005). Proliferating cell nuclear antigen promotes translesion synthesis by DNA polymerase zeta. Journal of Biological Chemistry, Vo.280, No.25, pp. 23446-23450

Genschel, J.; Bazemore, L.R. \& Modrich, P. (2002). Human exonuclease I is required for 5' and 3 ' mismatch repair. Journal of Biological Chemistry, Vo.277, No.15, pp. 1330213311 
Gilardini, A.; Marmiroli, P. \& Cavaletti, G. (2008). Proteasome Inhibition: A Promising Strategy for Treating Cancer, but What About Neurotoxicity? Current Medicinal Chemistry, Vo.15, No.29, pp. 3025-3035

Gillette, T.G.; Huang, W.; Russell, S.J.; Reed, S.H.; Johnston, S.A. \& Friedberg, E.C. (2001). The 195 complex of the proteasome regulates nucleotide excision repair in yeast. Genes and Development, Vo.15, No.12, pp. 1528-1539

Gillette, T.G.; Yu, S.; Zhou, Z.; Waters, R.; Johnston, S.A. \& Reed, S.H. (2006). Distinct functions of the ubiquitin-proteasome pathway influence nucleotide excision repair. EMBO Journal, Vo.25, No.11, pp. 2529-2538

Gocke, C.B.; Yu, H. \& Kang, J. (2005). Systematic identification and analysis of mammalian small ubiquitin-like modifier substrates. Journal of Biological Chemistry, Vo.280, No.6, pp. 5004-5012

Goldberg, A.L.; Cascio, P.; Saric, T. \& Rock, K.L. (2002). The importance of the proteasome and subsequent proteolytic steps in the generation of antigenic peptides. Molecular Immunology, Vo.39, No.3-4, pp. 147-164

Gong, F.; Fahy, D. \& Smerdon, M.J. (2006). Rad4-Rad23 interaction with SWI/SNF links ATP-dependent chromatin remodeling with nucleotide excision repair. Nat Struct Mol Biol, Vo.13, No.10, pp. 902-907

Gottlieb, T.M. \& Jackson, S.P. (1993). The DNA-dependent protein kinase: requirement for DNA ends and association with Ku antigen. Cell, Vo.72, No.1, pp. 131-142

Groisman, R.; Polanowska, J.; Kuraoka, I.; Sawada, J.; Saijo, M.; Drapkin, R.; Kisselev, A.F.; Tanaka, K. \& Nakatani, Y. (2003). The ubiquitin ligase activity in the DDB2 and CSA complexes is differentially regulated by the COP9 signalosome in response to DNA damage. Cell, Vo.113, No.3, pp. 357-367

Groll, M.; Ditzel, L.; Lowe, J.; Stock, D.; Bochtler, M.; Bartunik, H.D. \& Huber, R. (1997). Structure of $20 \mathrm{~S}$ proteasome from yeast at 2.4 A resolution. Nature, Vo.386, No.6624, pp. $463-471$

Groll, M.; Huber, R. \& Moroder, L. (2009). The persisting challenge of selective and specific proteasome inhibition. Journal of Peptide Science, Vo.15, No.2, pp. 58-66

Gudmundsdottir, K.; Lord, C.J. \& Ashworth, A. (2007). The proteasome is involved in determining differential utilization of double-strand break repair pathways. Oncogene, Vo.26, No.54, pp. 7601-7606

Guzder, J.; Paris, J.; Zelkowitz, P. \& Feldman, R. (1999). Psychological risk factors for borderline pathology in school-age children. Journal of the American Academy of Child and Adolescent Psychiatry, Vo.38, No.2, pp. 206-212

Guzder, S.N.; Sung, P.; Prakash, L. \& Prakash, S. (1998). Affinity of yeast nucleotide excision repair factor 2, consisting of the Rad4 and Rad23 proteins, for ultraviolet damaged DNA. Journal of Biological Chemistry, Vo.273, No.47, pp. 31541-31546

Halas, A.; Podlaska, A.; Derkacz, J.; McIntyre, J.; Skoneczna, A. \& Sledziewska-Gojska, E. (2011). The roles of PCNA SUMOylation, Mms2-Ubc13 and Rad5 in translesion DNA synthesis in Saccharomyces cerevisiae. Molecular Microbiology, Vo., pp.

Hanna, J. \& Finley, D. (2007). A proteasome for all occasions. FEBS Letters, Vo.581, No.15, pp. 2854-2861

Hardeland, U.; Kunz, C.; Focke, F.; Szadkowski, M. \& Schar, P. (2007). Cell cycle regulation as a mechanism for functional separation of the apparently redundant uracil DNA glycosylases TDG and UNG2. Nucleic Acids Res, Vo.35, No.11, pp. 3859-3867 
Hardeland, U.; Steinacher, R.; Jiricny, J. \& Schar, P. (2002a). Modification of the human thymine-DNA glycosylase by ubiquitin-like proteins facilitates enzymatic turnover. EMBO J, Vo.21, No.6, pp. 1456-1464

Hardeland, U.; Steinacher, R.; Jiricny, J. \& Schar, P. (2002b). Modification of the human thymine-DNA glycosylase by ubiquitin-like proteins facilitates enzymatic turnover. EMBO Journal, Vo.21, No.6, pp. 1456-1464

Hashizume, R.; Fukuda, M.; Maeda, I.; Nishikawa, H.; Oyake, D.; Yabuki, Y.; Ogata, H. \& Ohta, T. (2001). The RING heterodimer BRCA1-BARD1 is a ubiquitin ligase inactivated by a breast cancer-derived mutation. Journal of Biological Chemistry, Vo.276, No.18, pp. 14537-14540

Heinrich, M.C.; Silvey, K.V.; Stone, S.; Zigler, A.J.; Griffith, D.J.; Montalto, M.; Chai, L.; Zhi, Y. \& Hoatlin, M.E. (2000). Posttranscriptional cell cycle-dependent regulation of human FANCC expression. Blood, Vo.95, No.12, pp. 3970-3977

Hernandez-Pigeon, H.; Laurent, G.; Humbert, O.; Salles, B. \& Lautier, D. (2004). Degadration of mismatch repair hMutSalpha heterodimer by the ubiquitin-proteasome pathway. FEBS letters, Vo.562, No.1-3, pp. 40-44

Hernandez-Pigeon, H.; Quillet-Mary, A.; Louat, T.; Schambourg, A.; Humbert, O.; Selves, J.; Salles, B.; Laurent, G. \& Lautier, D. (2005). hMutS alpha is protected from ubiquitinproteasome-dependent degradation by atypical protein kinase $\mathrm{C}$ zeta phosphorylation. Journal of molecular biology, Vo.348, No.1, pp. 63-74

Herrmann, J.; Lerman, L.O. \& Lerman, A. (2007). Ubiquitin and ubiquitin-like proteins in protein regulation. Circulation Research, Vo.100, No.9, pp. 1276-1291

Hershko, A.; Ciechanover, A.; Heller, H.; Haas, A.L. \& Rose, I.A. (1980). Proposed Role of Atp in Protein Breakdown - Conjugation of Proteins with Multiple Chains of the Polypeptide of Atp-Dependent Proteolysis. Proceedings of the National Academy of Sciences of the United States of America-Biological Sciences, Vo.77, No.4, pp. 1783-1786

Hershko, A.; Ciechanover, A. \& Varshavsky, A. (2000). The ubiquitin system. Nature Medicine, Vo.6, No.10, pp. 1073-1081

Hideshima, T.; Richardson, P.; Chauhan, D.; Palombella, V.J.; Elliott, P.J.; Adams, J. \& Anderson, K.C. (2001). The proteasome inhibitor PS-341 inhibits growth, induces apoptosis, and overcomes drug resistance in human multiple myeloma cells. Cancer Research, Vo.61, No.7, pp. 3071-3076

Hoege, C.; Pfander, B.; Moldovan, G.L.; Pyrowolakis, G. \& Jentsch, S. (2002). RAD6dependent DNA repair is linked to modification of PCNA by ubiquitin and SUMO. Nature, Vo.419, No.6903, pp. 135-141

Hofmann, K. (2009). Ubiquitin-binding domains and their role in the DNA damage response. DNA Repair (Amst), Vo.8, No.4, pp. 544-556

Hori, T.; Osaka, F.; Chiba, T.; Miyamoto, C.; Okabayashi, K.; Shimbara, N.; Kato, S. \& Tanaka, K. (1999). Covalent modification of all members of human cullin family proteins by NEDD8. Oncogene, Vo.18, No.48, pp. 6829-6834

Hough, R.; Pratt, G. \& Rechsteiner, M. (1986). Ubiquitin-lysozyme conjugates. Identification and characterization of an ATP-dependent protease from rabbit reticulocyte lysates. Journal of Biological Chemistry, Vo.261, No.5, pp. 2400-2408

Huang, L. \& Chen, C.H. (2009). Proteasome Regulators: Activators and Inhibitors. Current Medicinal Chemistry, Vo.16, No.8, pp. 931-939 
Huang, T.T. \& D'andrea, A.D. (2006). Regulation of DNA repair by ubiquitylation. Nature Reviews Molecular Cell Biology, Vo.7, No.5, pp. 323-334

Huang, T.T.; Nijman, S.M.; Mirchandani, K.D.; Galardy, P.J.; Cohn, M.A.; Haas, W.; Gygi, S.P.; Ploegh, H.L.; Bernards, R. \& D'Andrea, A.D. (2006). Regulation of monoubiquitinated PCNA by DUB autocleavage. Nature cell biology, Vo.8, No.4, pp. 339-347

Huen, M.S.; Grant, R.; Manke, I.; Minn, K.; Yu, X.; Yaffe, M.B. \& Chen, J. (2007). RNF8 transduces the DNA-damage signal via histone ubiquitylation and checkpoint protein assembly. Cell, Vo.131, No.5, pp. 901-914

Humbert, O.; Hermine, T.; Hernandez, H.; Bouget, T.; Selves, J.; Laurent, G.; Salles, B. \& Lautier, D. (2002). Implication of protein kinase $C$ in the regulation of DNA mismatch repair protein expression and function. Journal of Biological Chemistry, Vo.277, No.20, pp. 18061-18068

Iovine, B.; Iannella, M.L. \& Bevilacqua, M.A. (2011). Damage-specific DNA binding protein 1 (DDB1) is involved in ubiquitin-mediated proteolysis of p27(Kip1) in response to UV irradiation. Biochimie, Vo., pp.

Jacquemont, C. \& Taniguchi, T. (2007). Proteasome function is required for DNA damage response and fanconi anemia pathway activation. Cancer Research, Vo.67, No.15, pp. 7395-7405

Jansen, L.E.; Verhage, R.A. \& Brouwer, J. (1998). Preferential binding of yeast Rad4.Rad23 complex to damaged DNA. Journal of Biological Chemistry, Vo.273, No.50, pp. 3311133114

Jelinsky, S.A.; Estep, P.; Church, G.M. \& Samson, L.D. (2000). Regulatory networks revealed by transcriptional profiling of damaged Saccharomyces cerevisiae cells: Rpn4 links base excision repair with proteasomes. Molecular and Cellular Biology, Vo.20, No.21, pp. $8157-8167$

Jentsch, S.; McGrath, J.P. \& Varshavsky, A. (1987). The yeast DNA repair gene RAD6 encodes a ubiquitin-conjugating enzyme. Nature, Vo.329, No.6135, pp. 131-134

Jiricny, J. (1998). Replication errors: cha(lle)nging the genome. The EMBO journal, Vo.17, No.22, pp. 6427-6436

Johnson, E.S. (2004). Protein modification by SUMO. Annual Review of Biochemistry, Vo.73, pp. 355-382

Ju, D.; Wang, X.; Ha, S.W.; Fu, J. \& Xie, Y. (2010). Inhibition of proteasomal degradation of rpn4 impairs nonhomologous end-joining repair of DNA double-strand breaks. PloS one, Vo.5, No.4, pp. e9877

Kannouche, P.L.; Wing, J. \& Lehmann, A.R. (2004). Interaction of human DNA polymerase eta with monoubiquitinated PCNA: a possible mechanism for the polymerase switch in response to DNA damage. Molecular Cell, Vo.14, No.4, pp. 491-500

Kennedy, R.D. \& D'Andrea, A.D. (2005). The Fanconi Anemia/BRCA pathway: new faces in the crowd. Genes and Development, Vo.19, No.24, pp. 2925-2940

Kisselev, A.F.; Akopian, T.N.; Woo, K.M. \& Goldberg, A.L. (1999). The sizes of peptides generated from protein by mammalian 26 and $20 \mathrm{~S}$ proteasomes. Implications for understanding the degradative mechanism and antigen presentation. Journal of Biological Chemistry, Vo.274, No.6, pp. 3363-3371

Kolas, N.K.; Chapman, J.R.; Nakada, S.; Ylanko, J.; Chahwan, R.; Sweeney, F.D.; Panier, S.; Mendez, M.; Wildenhain, J.; Thomson, T.M.; Pelletier, L.; Jackson, S.P. \& Durocher, 
D. (2007). Orchestration of the DNA-damage response by the RNF8 ubiquitin ligase. Science, Vo.318, No.5856, pp. 1637-1640

Kolodner, R.D. \& Marsischky, G.T. (1999). Eukaryotic DNA mismatch repair. Current opinion in genetics $\mathcal{E}$ development, Vo.9, No.1, pp. 89-96

Kratz, K.; Schopf, B.; Kaden, S.; Sendoel, A.; Eberhard, R.; Lademann, C.; Cannavo, E.; Sartori, A.A.; Hengartner, M.O. \& Jiricny, J. (2010). Deficiency of FANCD2associated nuclease KIAA1018/FAN1 sensitizes cells to interstrand crosslinking agents. Cell, Vo.142, No.1, pp. 77-88

Kristensen, C.N.; Bystol, K.M.; Li, B.; Serrano, L. \& Brenneman, M.A. (2010). Depletion of DSS1 protein disables homologous recombinational repair in human cells. Mutation research, Vo.694, No.1-2, pp. 60-64

Krogan, N.J.; Lam, M.H.; Fillingham, J.; Keogh, M.C.; Gebbia, M.; Li, J.; Datta, N.; Cagney, G.; Buratowski, S.; Emili, A. \& Greenblatt, J.F. (2004). Proteasome involvement in the repair of DNA double-strand breaks. Molecular cell, Vo.16, No.6, pp. 1027-1034

Lee, K.Y. \& Myung, K. (2008). PCNA modifications for regulation of post-replication repair pathways. Molecules and cells, Vo.26, No.1, pp. 5-11

Leibeling, D.; Laspe, P. \& Emmert, S. (2006). Nucleotide excision repair and cancer. J Mol Histol, Vo.37, No.5-7, pp. 225-238

Li, G.M. (2008). Mechanisms and functions of DNA mismatch repair. Cell Research, Vo.18, No.1, pp. 85-98

Li, W.; Hesabi, B.; Babbo, A.; Pacione, C.; Liu, J.; Chen, D.J.; Nickoloff, J.A. \& Shen, Z. (2000). Regulation of double-strand break-induced mammalian homologous recombination by UBL1, a RAD51-interacting protein. Nucleic Acids Res, Vo.28, No.5, pp. 1145-1153

Li, X. \& Heyer, W.D. (2008). Homologous recombination in DNA repair and DNA damage tolerance. Cell research, Vo.18, No.1, pp. 99-113

Liggett, A.; Crawford, L.J.; Walker, B.; Morris, T.C.M. \& Irvine, A.E. (2010). Methods for measuring proteasome activity: Current limitations and future developments. Leukemia Research, Vo.34, No.11, pp. 1403-1409

Ling, C.; Ishiai, M.; Ali, A.M.; Medhurst, A.L.; Neveling, K.; Kalb, R.; Yan, Z.; Xue, Y.; Oostra, A.B.; Auerbach, A.D.; Hoatlin, M.E.; Schindler, D.; Joenje, H.; de Winter, J.P.; Takata, M.; Meetei, A.R. \& Wang, W. (2007). FAAP100 is essential for activation of the Fanconi anemia-associated DNA damage response pathway. EMBO Journal, Vo.26, No.8, pp. 2104-2114

Liu, T.; Ghosal, G.; Yuan, J.; Chen, J. \& Huang, J. (2010). FAN1 acts with FANCI-FANCD2 to promote DNA interstrand cross-link repair. Science, Vo.329, No.5992, pp. 693-696

Lommel, L.; Chen, L.; Madura, K. \& Sweder, K. (2000). The 26S proteasome negatively regulates the level of overall genomic nucleotide excision repair. Nucleic Acids Res, Vo.28, No.24, pp. 4839-4845

Lommel, L.; Ortolan, T.; Chen, L.; Madura, K. \& Sweder, K.S. (2002). Proteolysis of a nucleotide excision repair protein by the $26 \mathrm{~S}$ proteasome. Current Genetics, Vo.42, No.1, pp. 9-20

Machida, Y.J.; Machida, Y.; Chen, Y.; Gurtan, A.M.; Kupfer, G.M.; D'Andrea, A.D. \& Dutta, A. (2006). UBE2T is the E2 in the Fanconi anemia pathway and undergoes negative autoregulation. Molecular Cell, Vo.23, No.4, pp. 589-596 
MacKay, C.; Declais, A.C.; Lundin, C.; Agostinho, A.; Deans, A.J.; MacArtney, T.J.; Hofmann, K.; Gartner, A.; West, S.C.; Helleday, T.; Lilley, D.M. \& Rouse, J. (2010). Identification of KIAA1018/FAN1, a DNA repair nuclease recruited to DNA damage by monoubiquitinated FANCD2. Cell, Vo.142, No.1, pp. 65-76

Magill, L.; Walker, B. \& Irvine, A.E. (2003). The proteasome: a novel therapeutic target in haematopoietic malignancy. Hematology, Vo.8, No.5, pp. 275-283

Mailand, N.; Bekker-Jensen, S.; Faustrup, H.; Melander, F.; Bartek, J.; Lukas, C. \& Lukas, J. (2007). RNF8 ubiquitylates histones at DNA double-strand breaks and promotes assembly of repair proteins. Cell, Vo.131, No.5, pp. 887-900

Mao, P. \& Smerdon, M.J. (2010). Yeast deubiquitinase Ubp3 interacts with the 26 S proteasome to facilitate Rad4 degradation. Journal of Biological Chemistry, Vo.285, No.48, pp. 37542-37550

Marston, N.J.; Richards, W.J.; Hughes, D.; Bertwistle, D.; Marshall, C.J. \& Ashworth, A. (1999). Interaction between the product of the breast cancer susceptibility gene BRCA2 and DSS1, a protein functionally conserved from yeast to mammals. Molecular and cellular biology, Vo.19, No.7, pp. 4633-4642

Masson, M.; Menissier-de Murcia, J.; Mattei, M.G.; de Murcia, G. \& Niedergang, C.P. (1997). Poly(ADP-ribose) polymerase interacts with a novel human ubiquitin conjugating enzyme: hUbc9. Gene, Vo.190, No.2, pp. 287-296

Masutani, C.; Araki, M.; Sugasawa, K.; van der Spek, P.J.; Yamada, A.; Uchida, A.; Maekawa, T.; Bootsma, D.; Hoeijmakers, J.H. \& Hanaoka, F. (1997). Identification and characterization of XPC-binding domain of hHR23B. Molecular and Cellular Biology, Vo.17, No.12, pp. 6915-6923

Matsushita, N.; Kitao, H.; Ishiai, M.; Nagashima, N.; Hirano, S.; Okawa, K.; Ohta, T.; Yu, D.S.; McHugh, P.J.; Hickson, I.D.; Venkitaraman, A.R.; Kurumizaka, H. \& Takata, M. (2005). A FancD2-monoubiquitin fusion reveals hidden functions of Fanconi anemia core complex in DNA repair. Molecular Cell, Vo.19, No.6, pp. 841-847

McConkey, D.J. \& Zhu, K. (2008). Mechanisms of proteasome inhibitor action and resistance in cancer. Drug Resist Updat, Vo.11, No.4-5, pp. 164-179

McIntyre, J.; Podlaska, A.; Skoneczna, A.; Halas, A. \& Sledziewska-Gojska, E. (2006). Analysis of the spontaneous mutator phenotype associated with $20 \mathrm{~S}$ proteasome deficiency in S. cerevisiae. Mutation research, Vo.593, No.1-2, pp. 153-163

Meetei, A.R.; de Winter, J.P.; Medhurst, A.L.; Wallisch, M.; Waisfisz, Q.; van de Vrugt, H.J.; Oostra, A.B.; Yan, Z.; Ling, C.; Bishop, C.E.; Hoatlin, M.E.; Joenje, H. \& Wang, W. (2003). A novel ubiquitin ligase is deficient in Fanconi anemia. Nature Genetics, Vo.35, No.2, pp. 165-170

Memisoglu, A. \& Samson, L. (2000). Base excision repair in yeast and mammals. Mutation Research, Vo.451, No.1-2, pp. 39-51

Messner, S.; Schuermann, D.; Altmeyer, M.; Kassner, I.; Schmidt, D.; Schar, P.; Muller, S. \& Hottiger, M.O. (2009). Sumoylation of poly(ADP-ribose) polymerase 1 inhibits its acetylation and restrains transcriptional coactivator function. FASEB Journal, Vo.23, No.11, pp. 3978-3989

Mimnaugh, E.G.; Yunmbam, M.K.; Li, Q.; Bonvini, P.; Hwang, S.G.; Trepel, J.; Reed, E. \& Neckers, L. (2000). Prevention of cisplatin-DNA adduct repair and potentiation of cisplatin-induced apoptosis in ovarian carcinoma cells by proteasome inhibitors. Biochemical Pharmacology, Vo.60, No.9, pp. 1343-1354 
Miyase, S.; Tateishi, S.; Watanabe, K.; Tomita, K.; Suzuki, K.; Inoue, H. \& Yamaizumi, M. (2005). Differential regulation of Rad18 through Rad6-dependent mono- and polyubiquitination. The Journal of biological chemistry, Vo.280, No.1, pp. 515-524

Modrich, P. \& Lahue, R. (1996). Mismatch repair in replication fidelity, genetic recombination, and cancer biology. Annual Review of Biochemistry, Vo.65, pp. 101133

Moschos, S.J. \& Mo, Y.Y. (2006). Role of SUMO/Ubc9 in DNA damage repair and tumorigenesis. J Mol Histol, Vo.37, No.5-7, pp. 309-319

Motegi, A.; Murakawa, Y. \& Takeda, S. (2009). The vital link between the ubiquitinproteasome pathway and DNA repair: Impact on cancer therapy. Cancer Letters, Vo.283, No.1, pp. 1-9

Mueller, J.P. \& Smerdon, M.J. (1996). Rad23 is required for transcription-coupled repair and efficient overrall repair in Saccharomyces cerevisiae. Molecular and Cellular Biology, Vo.16, No.5, pp. 2361-2368

Murakawa, Y.; Sonoda, E.; Barber, L.J.; Zeng, W.; Yokomori, K.; Kimura, H.; Niimi, A.; Lehmann, A.; Zhao, G.Y.; Hochegger, H.; Boulton, S.J. \& Takeda, S. (2007). Inhibitors of the proteasome suppress homologous DNA recombination in mammalian cells. Cancer Research, Vo.67, No.18, pp. 8536-8543

Naiki, H. \& Nagai, Y. (2009). Molecular Pathogenesis of Protein Misfolding Diseases: Pathological Molecular Environments Versus Quality Control Systems Against Misfolded Proteins. Journal of Biochemistry, Vo.146, No.6, pp. 751-756

Nakamura, K.; Sakai, W.; Kawamoto, T.; Bree, R.T.; Lowndes, N.F.; Takeda, S. \& Taniguchi, Y. (2006). Genetic dissection of vertebrate 53BP1: a major role in non-homologous end joining of DNA double strand breaks. DNA Repair (Amst), Vo.5, No.6, pp. 741749

Navon, A. \& Ciechanover, A. (2009). The 26 S Proteasome: From Basic Mechanisms to Drug Targeting. Journal of Biological Chemistry, Vo.284, No.49, pp. 33713-33718

Nijman, S.M.; Huang, T.T.; Dirac, A.M.; Brummelkamp, T.R.; Kerkhoven, R.M.; D'Andrea, A.D. \& Bernards, R. (2005). The deubiquitinating enzyme USP1 regulates the Fanconi anemia pathway. Molecular Cell, Vo.17, No.3, pp. 331-339

Ohuchi, T.; Seki, M.; Branzei, D.; Maeda, D.; Ui, A.; Ogiwara, H.; Tada, S. \& Enomoto, T. (2008). Rad52 sumoylation and its involvement in the efficient induction of homologous recombination. DNA Repair (Amst), Vo.7, No.6, pp. 879-889

Orlowski, M. \& Wilk, S. (2000). Catalytic activities of the $20 \mathrm{~S}$ proteasome, a multicatalytic proteinase complex. Archives of Biochemistry and Biophysics, Vo.383, No.1, pp. 1-16

Orlowski, R.Z. \& Kuhn, D.J. (2008). Proteasome inhibitors in cancer therapy: Lessons from the first decade. Clinical Cancer Research, Vo.14, No.6, pp. 1649-1657

Ortolan, T.G.; Chen, L.; Tongaonkar, P. \& Madura, K. (2004). Rad23 stabilizes Rad4 from degradation by the Ub/proteasome pathway. Nucleic Acids Res, Vo.32, No.22, pp. 6490-6500

Ortolan, T.G.; Tongaonkar, P.; Lambertson, D.; Chen, L.; Schauber, C. \& Madura, K. (2000). The DNA repair protein rad23 is a negative regulator of multi-ubiquitin chain assembly. Nat Cell Biol, Vo.2, No.9, pp. 601-608

Palombella, V.J.; Conner, E.M.; Fuseler, J.W.; Destree, A.; Davis, J.M.; Laroux, F.S.; Wolf, R.E.; Huang, J.; Brand, S.; Elliott, P.J.; Lazarus, D.; McCormack, T.; Parent, L.; Stein, R.; Adams, J. \& Grisham, M.B. (1998). Role of the proteasome and NF-kappaB in 
streptococcal cell wall-induced polyarthritis. Proceedings of the National Academy of Sciences of the United States of America, Vo.95, No.26, pp. 15671-15676

Pang, Q. \& Andreassen, P.R. (2009). Fanconi anemia proteins and endogenous stresses. Mutation Research, Vo.668, No.1-2, pp. 42-53

Papouli, E.; Chen, S.; Davies, A.A.; Huttner, D.; Krejci, L.; Sung, P. \& Ulrich, H.D. (2005). Crosstalk between SUMO and ubiquitin on PCNA is mediated by recruitment of the helicase Srs2p. Molecular Cell, Vo.19, No.1, pp. 123-133

Parsons, J.L.; Dianova, II; Finch, D.; Tait, P.S.; Strom, C.E.; Helleday, T. \& Dianov, G.L. (2010). XRCC1 phosphorylation by CK2 is required for its stability and efficient DNA repair. DNA Repair (Amst), Vo.9, No.7, pp. 835-841

Parsons, J.L.; Tait, P.S.; Finch, D.; Dianova, II; Allinson, S.L. \& Dianov, G.L. (2008a). CHIPmediated degradation and DNA damage-dependent stabilization regulate base excision repair proteins. Mol Cell, Vo.29, No.4, pp. 477-487

Parsons, J.L.; Tait, P.S.; Finch, D.; Dianova, II; Allinson, S.L. \& Dianov, G.L. (2008b). CHIPmediated degradation and DNA damage-dependent stabilization regulate base excision repair proteins. Molecular Cell, Vo.29, No.4, pp. 477-487

Paunesku, T.; Mittal, S.; Protic, M.; Oryhon, J.; Korolev, S.V.; Joachimiak, A. \& Woloschak, G.E. (2001). Proliferating cell nuclear antigen (PCNA): ringmaster of the genome. International journal of radiation biology, Vo.77, No.10, pp. 1007-1021

Pfander, B.; Moldovan, G.L.; Sacher, M.; Hoege, C. \& Jentsch, S. (2005). SUMO-modified PCNA recruits Srs2 to prevent recombination during $S$ phase. Nature, Vo.436, No.7049, pp. 428-433

Plosky, B.S.; Vidal, A.E.; Fernandez de Henestrosa, A.R.; McLenigan, M.P.; McDonald, J.P.; Mead, S. \& Woodgate, R. (2006). Controlling the subcellular localization of DNA polymerases iota and eta via interactions with ubiquitin. The EMBO journal, Vo.25, No.12, pp. 2847-2855

Podlaska, A.; McIntyre, J.; Skoneczna, A. \& Sledziewska-Gojska, E. (2003). The link between $20 S$ proteasome activity and post-replication DNA repair in Saccharomyces cerevisiae. Molecular microbiology, Vo.49, No.5, pp. 1321-1332

Postow, L.; Ghenoiu, C.; Woo, E.M.; Krutchinsky, A.N.; Chait, B.T. \& Funabiki, H. (2008). Ku80 removal from DNA through double strand break-induced ubiquitylation. The Journal of cell biology, Vo.182, No.3, pp. 467-479

Prakash, S.; Johnson, R.E. \& Prakash, L. (2005). Eukaryotic translesion synthesis DNA polymerases: specificity of structure and function. Annual Review of Biochemistry, Vo.74, pp. 317-353

Ramos, P.C.; Hockendorff, J.; Johnson, E.S.; Varshavsky, A. \& Dohmen, R.J. (1998). Ump1p is required for proper maturation of the $20 \mathrm{~S}$ proteasome and becomes its substrate upon completion of the assembly. Cell, Vo.92, No.4, pp. 489-499

Ramsey, K.L.; Smith, J.J.; Dasgupta, A.; Maqani, N.; Grant, P. \& Auble, D.T. (2004). The NEF4 complex regulates Rad4 levels and utilizes Snf2/Swi2-related ATPase activity for nucleotide excision repair. Molecular and Cellular Biology, Vo.24, No.14, pp. 6362-6378

Ribar, B.; Prakash, L. \& Prakash, S. (2006). Requirement of ELC1 for RNA polymerase II polyubiquitylation and degradation in response to DNA damage in Saccharomyces cerevisiae. Molecular and Cellular Biology, Vo.26, No.11, pp. 3999-4005 
Russell, S.J.; Reed, S.H.; Huang, W.; Friedberg, E.C. \& Johnston, S.A. (1999). The 19 S regulatory complex of the proteasome functions independently of proteolysis in nucleotide excision repair. Molecular Cell, Vo.3, No.6, pp. 687-695

Russo, A.; Fratto, M.E.; Bazan, V.; Schiro, V.; Agnese, V.; Cicero, G.; Vincenzi, B.; Tonini, G. \& Santini, D. (2007). Targeting apoptosis in solid tumors: the role of bortezomib from preclinical to clinical evidence. Expert Opinion on Therapeutic Targets, Vo.11, No.12, pp. 1571-1586

Sacher, M.; Pfander, B.; Hoege, C. \& Jentsch, S. (2006). Control of Rad52 recombination activity by double-strand break-induced SUMO modification. Nat Cell Biol, Vo.8, No.11, pp. 1284-1290

Sakasai, R. \& Tibbetts, R. (2008). RNF8-dependent and RNF8-independent regulation of 53BP1 in response to DNA damage. The Journal of biological chemistry, Vo.283, No.20, pp. 13549-13555

San Miguel, J.F.; Schlag, R.; Khuageva, N.K.; Dimopoulos, M.A.; Shpilberg, O.; Kropff, M.; Spicka, I.; Petrucci, M.T.; Palumbo, A.; Samoilova, O.S.; Dmoszynska, A.; Abdulkadyrov, K.M.; Schots, R.; Jiang, B.; Mateos, M.V.; Anderson, K.C.; Esseltine, D.L.; Liu, K.; Cakana, A.; van de Velde, H. \& Richardson, P.G. (2008). Bortezomib plus melphalan and prednisone for initial treatment of multiple myeloma. New England Journal of Medicine, Vo.359, No.9, pp. 906-917

Sartori, A.A.; Lukas, C.; Coates, J.; Mistrik, M.; Fu, S.; Bartek, J.; Baer, R.; Lukas, J. \& Jackson, S.P. (2007). Human CtIP promotes DNA end resection. Nature, Vo.450, No.7169, pp. 509-514

Schauber, C.; Chen, L.; Tongaonkar, P.; Vega, I.; Lambertson, D.; Potts, W. \& Madura, K. (1998). Rad23 links DNA repair to the ubiquitin/proteasome pathway. Nature, Vo.391, No.6668, pp. 715-718

Schmutte, C.; Sadoff, M.M.; Shim, K.S.; Acharya, S. \& Fishel, R. (2001). The interaction of DNA mismatch repair proteins with human exonuclease I. Journal of Biological Chemistry, Vo.276, No.35, pp. 33011-33018

Schwartz, A.L. \& Ciechanover, A. (2009). Targeting Proteins for Destruction by the Ubiquitin System: Implications for Human Pathobiology. Annual Review of Pharmacology and Toxicology, Vo.49, pp. 73-96

Shabek, N. \& Ciechanover, A. (2010). Degradation of ubiquitin The fate of the cellular reaper. Cell Cycle, Vo.9, No.3, pp. 523-530

Sharova, N.P. (2005a). How does a cell repair damaged DNA? Biochemistry-Moscow, Vo.70, No.3, pp. 275-291

Sharova, N.P. (2005b). How does a cell repair damaged DNA? Biochemistry (Mosc), Vo.70, No.3, pp. 275-291

Shen, Z.; Pardington-Purtymun, P.E.; Comeaux, J.C.; Moyzis, R.K. \& Chen, D.J. (1996). UBL1, a human ubiquitin-like protein associating with human RAD51/RAD52 proteins. Genomics, Vo.36, No.2, pp. 271-279

Skoneczna, A.; McIntyre, J.; Skoneczny, M.; Policinska, Z. \& Sledziewska-Gojska, E. (2007). Polymerase eta is a short-lived, proteasomally degraded protein that is temporarily stabilized following UV irradiation in Saccharomyces cerevisiae. Journal of Molecular Biology, Vo.366, No.4, pp. 1074-1086

Smogorzewska, A.; Desetty, R.; Saito, T.T.; Schlabach, M.; Lach, F.P.; Sowa, M.E.; Clark, A.B.; Kunkel, T.A.; Harper, J.W.; Colaiacovo, M.P. \& Elledge, S.J. (2010). A genetic screen 
identifies FAN1, a Fanconi anemia-associated nuclease necessary for DNA interstrand crosslink repair. Molecular Cell, Vo.39, No.1, pp. 36-47

Smogorzewska, A.; Matsuoka, S.; Vinciguerra, P.; McDonald, E.R., 3rd; Hurov, K.E.; Luo, J.; Ballif, B.A.; Gygi, S.P.; Hofmann, K.; D'Andrea, A.D. \& Elledge, S.J. (2007). Identification of the FANCI protein, a monoubiquitinated FANCD2 paralog required for DNA repair. Cell, Vo.129, No.2, pp. 289-301

Starita, L.M. \& Parvin, J.D. (2003). The multiple nuclear functions of BRCA1: transcription, ubiquitination and DNA repair. Current Opinion in Cell Biology, Vo.15, No.3, pp. 345-350

Stehmeier, P. \& Muller, S. (2009). Regulation of p53 family members by the ubiquitin-like SUMO system. DNA Repair (Amst), Vo.8, No.4, pp. 491-498

Steinacher, R. \& Schar, P. (2005a). Functionality of human thymine DNA glycosylase requires SUMO-regulated changes in protein conformation. Curr Biol, Vo.15, No.7, pp. 616-623

Steinacher, R. \& Schar, P. (2005b). Functionality of human thymine DNA glycosylase requires SUMO-regulated changes in protein conformation. Current Biology, Vo.15, No.7, pp. 616-623

Stelter, P. \& Ulrich, H.D. (2003). Control of spontaneous and damage-induced mutagenesis by SUMO and ubiquitin conjugation. Nature, Vo.425, No.6954, pp. 188-191

Stewart, G.S.; Panier, S.; Townsend, K.; Al-Hakim, A.K.; Kolas, N.K.; Miller, E.S.; Nakada, S.; Ylanko, J.; Olivarius, S.; Mendez, M.; Oldreive, C.; Wildenhain, J.; Tagliaferro, A.; Pelletier, L.; Taubenheim, N.; Durandy, A.; Byrd, P.J.; Stankovic, T.; Taylor, A.M. \& Durocher, D. (2009). The RIDDLE syndrome protein mediates a ubiquitindependent signaling cascade at sites of DNA damage. Cell, Vo.136, No.3, pp. 420434

Stewart, G.S.; Stankovic, T.; Byrd, P.J.; Wechsler, T.; Miller, E.S.; Huissoon, A.; Drayson, M.T.; West, S.C.; Elledge, S.J. \& Taylor, A.M. (2007). RIDDLE immunodeficiency syndrome is linked to defects in 53BP1-mediated DNA damage signaling. Proceedings of the National Academy of Sciences of the United States of America, Vo.104, No.43, pp. 16910-16915

Stoyanova, T.; Roy, N.; Kopanja, D.; Raychaudhuri, P. \& Bagchi, S. (2009). DDB2 (damagedDNA binding protein 2) in nucleotide excision repair and DNA damage response. Cell Cycle, Vo.8, No.24, pp. 4067-4071

Strom, C.E.; Johansson, F.; Uhlen, M.; Al-Khalili Szigyarto, C.; Erixon, K. \& Helleday, T. (2010). Poly (ADP-ribose) polymerase (PARP) is not involved in base excision repair but PARP inhibition traps a single-strand intermediate. Nucleic Acids Res, Vo., pp.

Takahashi, H.; Hatakeyama, S.; Saitoh, H. \& Nakayama, K.I. (2005). Noncovalent SUMO-1 binding activity of thymine DNA glycosylase (TDG) is required for its SUMO-1 modification and colocalization with the promyelocytic leukemia protein. Journal of Biological Chemistry, Vo.280, No.7, pp. 5611-5621

Takeshita, T.; Wu, W.W.; Koike, A.; Fukuda, M. \& Ohta, T. (2009). Perturbation of DNA repair pathways by proteasome inhibitors corresponds to enhanced chemosensitivity of cells to DNA damage-inducing agents. Cancer Chemotherapy and Pharmacology, Vo.64, No.5, pp. 1039-1046 
Takezawa, J.; Ishimi, Y. \& Yamada, K. (2008). Proteasome inhibitors remarkably prevent translesion replication in cancer cells but not normal cells. Cancer science, Vo.99, No.5, pp. 863-871

Tseng, H.M. \& Tomkinson, A.E. (2002). A physical and functional interaction between yeast Pol4 and Dnl4-Lif1 links DNA synthesis and ligation in nonhomologous end joining. Journal of Biological Chemistry, Vo.277, No.47, pp. 45630-45637

Ulrich, H.D. (2009). Regulating post-translational modifications of the eukaryotic replication clamp PCNA. DNA Repair, Vo.8, No.4, pp. 461-469

van der Spek, P.J.; Visser, C.E.; Hanaoka, F.; Smit, B.; Hagemeijer, A.; Bootsma, D. \& Hoeijmakers, J.H. (1996). Cloning, comparative mapping, and RNA expression of the mouse homologues of the Saccharomyces cerevisiae nucleotide excision repair gene RAD23. Genomics, Vo.31, No.1, pp. 20-27

Vandenberg, C.J.; Gergely, F.; Ong, C.Y.; Pace, P.; Mallery, D.L.; Hiom, K. \& Patel, K.J. (2003). BRCA1-independent ubiquitination of FANCD2. Molecular Cell, Vo.12, No.1, pp. 247-254

Varshavsky, A. (1997). The ubiquitin system. Trends in Biochemical Sciences, Vo.22, No.10, pp. 383-387

Vlachostergios, P.J.; Patrikidou, A.; Daliani, D.D. \& Papandreou, C.N. (2009a). The ubiquitin-proteasome system in cancer, a major player in DNA repair. Part 1: posttranslational regulation. J Cell Mol Med, Vo.13, No.9B, pp. 3006-3018

Vlachostergios, P.J.; Patrikidou, A.; Daliani, D.D. \& Papandreou, C.N. (2009b). The ubiquitin-proteasome system in cancer, a major player in DNA repair. Part 2: transcriptional regulation. Journal of Cellular and Molecular Medicine, Vo.13, No.9B, pp. 3019-3031

Wang, B. \& Elledge, S.J. (2007). Ubc13/Rnf8 ubiquitin ligases control foci formation of the Rap80/Abraxas/Brca1/Brcc36 complex in response to DNA damage. Proceedings of the National Academy of Sciences of the United States of America, Vo.104, No.52, pp. 20759-20763

Wang, Q.E.; Wani, M.A.; Chen, J.; Zhu, Q.; Wani, G.; El-Mahdy, M.A. \& Wani, A.A. (2005a). Cellular ubiquitination and proteasomal functions positively modulate mammalian nucleotide excision repair. Molecular Carcinogenesis, Vo.42, No.1, pp. 53-64

Wang, Q.E.; Zhu, Q.; Wani, G.; El-Mahdy, M.A.; Li, J. \& Wani, A.A. (2005b). DNA repair factor XPC is modified by SUMO-1 and ubiquitin following UV irradiation. Nucleic Acids Res, Vo.33, No.13, pp. 4023-4034

Wang, S.; Gong, Z.; Chen, R.; Liu, Y.; Li, A.; Li, G. \& Zhou, J. (2009). JWA regulates XRCC1 and functions as a novel base excision repair protein in oxidative-stress-induced DNA single-strand breaks. Nucleic Acids Res, Vo.37, No.6, pp. 1936-1950

Wang, T.; Simbulan-Rosenthal, C.M.; Smulson, M.E.; Chock, P.B. \& Yang, D.C. (2008). Polyubiquitylation of PARP-1 through ubiquitin K48 is modulated by activated DNA, NAD+, and dipeptides. Journal of Cellular Biochemistry, Vo.104, No.1, pp. 318328

Wang, Z.M.; Chen, Z.P.; Xu, Z.Y.; Christodoulopoulos, G.; Bello, V.; Mohr, G.; Aloyz, R. \& Panasci, L.C. (2001). In vitro evidence for homologous recombinational repair in resistance to melphalan. Journal of the National Cancer Institute, Vo.93, No.19, pp. 1473-1478 
Watanabe, K.; Tateishi, S.; Kawasuji, M.; Tsurimoto, T.; Inoue, H. \& Yamaizumi, M. (2004). Rad18 guides poleta to replication stalling sites through physical interaction and PCNA monoubiquitination. EMBO Journal, Vo.23, No.19, pp. 3886-3896

Waters, R.; Zhang, R. \& Jones, N.J. (1993). Inducible removal of UV-induced pyrimidine dimers from transcriptionally active and inactive genes of Saccharomyces cerevisiae. Molecular and General Genetics, Vo.239, No.1-2, pp. 28-32

Watkins, J.F.; Sung, P.; Prakash, L. \& Prakash, S. (1993). The Saccharomyces cerevisiae DNA repair gene RAD23 encodes a nuclear protein containing a ubiquitin-like domain required for biological function. Molecular and Cellular Biology, Vo.13, No.12, pp. 7757-7765

Waxman, L.; Fagan, J.M. \& Goldberg, A.L. (1987). Demonstration of two distinct high molecular weight proteases in rabbit reticulocytes, one of which degrades ubiquitin conjugates. Journal of Biological Chemistry, Vo.262, No.6, pp. 2451-2457

West, S.C. (2003). Molecular views of recombination proteins and their control. Nat Rev Mol Cell Biol, Vo.4, No.6, pp. 435-445

Wilkinson, K.D.; Urban, M.K. \& Haas, A.L. (1980). Ubiquitin is the ATP-dependent proteolysis factor I of rabbit reticulocytes. Journal of Biological Chemistry, Vo.255, No.16, pp. 7529-7532

Wilson, D.M., 3rd \& Thompson, L.H. (1997). Life without DNA repair. Proceedings of the National Academy of Sciences of the United States of America, Vo.94, No.24, pp. 1275412757

Wilson, S.H.; Beard, W.A.; Shock, D.D.; Batra, V.K.; Cavanaugh, N.A.; Prasad, R.; Hou, E.W.; Liu, Y.; Asagoshi, K.; Horton, J.K.; Stefanick, D.F.; Kedar, P.S.; Carrozza, M.J.; Masaoka, A. \& Heacock, M.L. (2010). Base excision repair and design of small molecule inhibitors of human DNA polymerase beta. Cellular and Molecular Life Sciences, Vo.67, No.21, pp. 3633-3647

Wiltrout, M.E. \& Walker, G.C. (2011). Proteasomal regulation of the mutagenic translesion DNA polymerase, Saccharomyces cerevisiae Rev1. DNA Repair (Amst), Vo.10, No.2, pp. 169-175

Woodhouse, B.C.; Dianova, II; Parsons, J.L. \& Dianov, G.L. (2008). Poly(ADP-ribose) polymerase-1 modulates DNA repair capacity and prevents formation of DNA double strand breaks. DNA Repair (Amst), Vo.7, No.6, pp. 932-940

Xia, Y.; Pao, G.M.; Chen, H.W.; Verma, I.M. \& Hunter, T. (2003). Enhancement of BRCA1 E3 ubiquitin ligase activity through direct interaction with the BARD1 protein. Journal of Biological Chemistry, Vo.278, No.7, pp. 5255-5263

Xie, Y. (2010). Structure, assembly and homeostatic regulation of the $26 \mathrm{~S}$ proteasome. J Mol Cell Biol, Vo.2, No.6, pp. 308-317

Xirodimas, D.P.; Saville, M.K.; Bourdon, J.C.; Hay, R.T. \& Lane, D.P. (2004). Mdm2-mediated NEDD8 conjugation of p53 inhibits its transcriptional activity. Cell, Vo.118, No.1, pp. 83-97

Yu, X.; Fu, S.; Lai, M.; Baer, R. \& Chen, J. (2006). BRCA1 ubiquitinates its phosphorylationdependent binding partner CtIP. Genes and Development, Vo.20, No.13, pp. 17211726

Yurchenko, V.; Xue, Z. \& Sadofsky, M.J. (2006). SUMO modification of human XRCC4 regulates its localization and function in DNA double-strand break repair. Molecular and Cellular Biology, Vo.26, No.5, pp. 1786-1794 
Zhang, Y. \& Xiong, Y. (2001). Control of p53 ubiquitination and nuclear export by MDM2 and ARF. Cell Growth Differ, Vo.12, No.4, pp. 175-186

Zhao, G.Y.; Sonoda, E.; Barber, L.J.; Oka, H.; Murakawa, Y.; Yamada, K.; Ikura, T.; Wang, X.; Kobayashi, M.; Yamamoto, K.; Boulton, S.J. \& Takeda, S. (2007). A critical role for the ubiquitin-conjugating enzyme Ubc13 in initiating homologous recombination. Molecular cell, Vo.25, No.5, pp. 663-675

Zhu, Q.; Wani, G.; Arab, H.H.; El-Mahdy, M.A.; Ray, A. \& Wani, A.A. (2009). Chromatin restoration following nucleotide excision repair involves the incorporation of ubiquitinated H2A at damaged genomic sites. DNA Repair (Amst), Vo.8, No.2, pp. 262-273

Zhu, Q.; Wani, G.; Yao, J.; Patnaik, S.; Wang, Q.E.; El-Mahdy, M.A.; Praetorius-Ibba, M. \& Wani, A.A. (2007). The ubiquitin-proteasome system regulates p53-mediated transcription at p21waf1 promoter. Oncogene, Vo.26, No.29, pp. 4199-4208

Zhuang, Z.; Johnson, R.E.; Haracska, L.; Prakash, L.; Prakash, S. \& Benkovic, S.J. (2008). Regulation of polymerase exchange between Poleta and Poldelta by monoubiquitination of PCNA and the movement of DNA polymerase holoenzyme. Proceedings of the National Academy of Sciences of the United States of America, Vo.105, No.14, pp. 5361-5366 


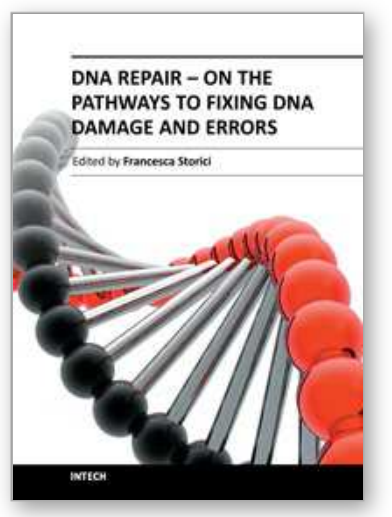

\author{
DNA Repair - On the Pathways to Fixing DNA Damage and Errors \\ Edited by Dr. Francesca Storici
}

ISBN 978-953-307-649-2

Hard cover, 380 pages

Publisher InTech

Published online 09, September, 2011

Published in print edition September, 2011

DNA repair is fundamental to all cell types to maintain genomic stability. A collection of cutting-edge reviews, DNA Repair - On the pathways to fixing DNA damage and errors covers major aspects of the DNA repair processes in a large variety of organisms, emphasizing foremost developments, questions to be solved and new directions in this rapidly evolving area of modern biology. Written by researchers at the vanguard of the DNA repair field, the chapters highlight the importance of the DNA repair mechanisms and their linkage to DNA replication, cell-cycle progression and DNA recombination. Major topics include: base excision repair, nucleotide excision repair, mismatch repair, double-strand break repair, with focus on specific inhibitors and key players of DNA repair such as nucleases, ubiquitin-proteasome enzymes, poly ADP-ribose polymerase and factors relevant for DNA repair in mitochondria and embryonic stem cells. This book is a journey into the cosmos of DNA repair and its frontiers.

\title{
How to reference
}

In order to correctly reference this scholarly work, feel free to copy and paste the following:

Christine A. Falaschetti, Emily C. Mirkin, Sumita Raha, Tatjana Paunesku and Gayle E. Woloschak (2011). The Ubiquitin-Proteasome System and DNA Repair, DNA Repair - On the Pathways to Fixing DNA Damage and Errors, Dr. Francesca Storici (Ed.), ISBN: 978-953-307-649-2, InTech, Available from:

http://www.intechopen.com/books/dna-repair-on-the-pathways-to-fixing-dna-damage-and-errors/the-ubiquitinproteasome-system-and-dna-repair

\section{INTECH}

open science | open minds

\section{InTech Europe}

University Campus STeP Ri

Slavka Krautzeka 83/A

51000 Rijeka, Croatia

Phone: +385 (51) 770447

Fax: +385 (51) 686166

www.intechopen.com

\section{InTech China}

Unit 405, Office Block, Hotel Equatorial Shanghai

No.65, Yan An Road (West), Shanghai, 200040, China

中国上海市延安西路65号上海国际贵都大饭店办公楼 405 单元

Phone: +86-21-62489820

Fax: +86-21-62489821 
(C) 2011 The Author(s). Licensee IntechOpen. This chapter is distributed under the terms of the Creative Commons Attribution-NonCommercialShareAlike-3.0 License, which permits use, distribution and reproduction for non-commercial purposes, provided the original is properly cited and derivative works building on this content are distributed under the same license. 